\title{
Tectono-metamorphic evolution of shallow crustal levels within active volcanic arcs. Insights from the exhumed Basal Complex of Basse-Terre (Guadeloupe, French West Indies)
}

\author{
Alexiane Favier, ${ }^{1,2}$, Jean-Marc Lardeaux ${ }^{2,3}$, Lucie Legendre ${ }^{1}$, Chrystele Verati ${ }^{2}$, Melody Philippon ${ }^{1}$, \\ Michel Corsini ${ }^{2}$, Philippe Münch ${ }^{4}$ and Sandra Ventalon ${ }^{5}$ \\ ${ }^{1}$ UMR 5243 Géosciences Montpellier, Université des Antilles-CNRS-Université de Montpellier, Campus de Fouillole, \\ 97159 Pointe à Pitre Cedex, Guadeloupe, France \\ ${ }^{2}$ UMR 7329 Geoazur, Université de Nice Sophia Antipolis, Observatoire de la Côte d'Azur, 250, rue Albert Einstein, Sophia Antipolis, \\ 06560 Valbonne, France \\ ${ }^{3}$ Czech Geological Survey, Centre for Lithospheric Research, Klárov 3, 11821 Prague 1, Czech Republic \\ ${ }^{4}$ UMR 5243 Géosciences Montpellier, Université de Montpellier-CNRS-Université des Antilles, Place Eugène Bataillon, \\ 34095 Montpellier, France \\ ${ }^{5}$ UMR 8187 Laboratoire d'Océanologie et de Géosciences, Université de Lille, Avenue Paul Langevin, 59655 Villeneuve d'Ascq, France
}

Received: 7 March 2019 / Accepted: 18 August 2019

\begin{abstract}
In order to decipher the tectono-metamorphic evolution of shallow crustal levels of the active volcanic arc of the Guadeloupe archipelago (Lesser Antilles) we present new geochemical, geochronological, mineralogical and structural investigations of the so-called Basal Complex, the oldest and most eroded volcanic complex of Basse-Terre in Guadeloupe. Based on geochemical and mineralogical criteria we propose an updated geological map of this northern area of Basse-Terre. Using ${ }^{40} \mathrm{Ar}-{ }^{39} \mathrm{Ar}$ geochronology we demonstrate first that the eroded "Gros Morne" of Deshaies belong to the Basal Complex, and second that this complex is characterized by 4.3 to $2 \mathrm{Ma}$ old volcanism. Structural analysis reveals a long-lived deformation history with the development through time of N80-N100 schistose zones; N110N140 and N160-N10 oriented hydrothermal breccias and N140-N150 brittle normal faults. The boundary between the Basal Complex and the southernmost Septentrional Chain corresponds to a series of faults with $\mathrm{N} 150^{\circ}$ and $\mathrm{N} 50^{\circ}$ main directions. Detailed mineralogical and petrological investigations, including thermodynamic modeling, allow the identification of three phases of post-magmatic mineralogical transformations with first a high-temperature stage under Greenschist to sub-Greenschist facies conditions $\left(0.6-2 \mathrm{kbar}\right.$ for $\left.250-300^{\circ} \mathrm{C}\right)$, a re-equilibration under Zeolite facies conditions and finally a sub-surface alteration. The consistency between $\mathrm{P}-\mathrm{T}$ conditions of metamorphism and the present day measured geothermal gradient demonstrates that the metamorphic pattern is the record of hydrothermal fluids circulation during building and cooling of the Lesser Antilles magmatic arc. The tectono-metamorphic evolution recognized in the Basal Complex enables us to propose a conceptual model for heat and fluid transport within shallow crustal levels of the Guadeloupe active volcanic arc.
\end{abstract}

Keywords: arc-related metamorphism / Lesser Antilles / Guadeloupe / Basal Complex / tectono-metamorphic evolution / hydrothermal fluids

Résumé - Évolution tectono-métamorphique des niveaux superficiels de la croûte dans les arcs volcaniques actifs. Exemple du Complexe Basal exhumé de Basse-Terre (Guadeloupe, Antilles françaises). Afin de décrypter l'évolution tectono-métamorphique des niveaux crustaux peu profonds de l'arc volcanique actif de l'archipel de la Guadeloupe (Petites Antilles), nous présentons de nouvelles investigations géochimiques, géochronologiques, minéralogiques et structurales du Complexe Basal, le plus ancien et le plus érodé des complexes volcaniques de Basse-Terre en Guadeloupe. Sur la base de critères géochimiques et minéralogiques, nous proposons une carte géologique actualisée de cette zone nord de la Basse-Terre. En utilisant la géochronologie ${ }^{40} \mathrm{Ar}-{ }^{39} \mathrm{Ar}$ nous démontrons d'abord que le « Gros Morne»

*Corresponding author: favier@geoazur.unice.fr 
érodé de Deshaies appartient au Complexe Basal, ensuite que ce complexe est caractérisé par un épisode volcanique actif entre 4,3 et $2 \mathrm{Ma}$. L'analyse structurale révèle une histoire de déformation significative avec le développement dans le temps de zones schisteuses N80-N100, de brèches hydrothermales orientées N110-N140 et N160-N10 et de failles normales N140-N150 majoritairement. La limite entre le Complexe Basal et la Chaîne Septentrionale correspond à une série de failles dont les directions principales sont $\mathrm{N} 150^{\circ}$ et $\mathrm{N} 50^{\circ}$. Des études minéralogiques et pétrologiques détaillées, incluant la modélisation thermodynamique, permettent d'identifier trois phases de transformations minéralogiques post-magmatiques avec d'abord un épisode de haute-température dans des conditions de faciès de Schistes-Verts à sub-Schistes-Verts $(0,6-$ $2 \mathrm{kbar}$ pour $250-300^{\circ} \mathrm{C}$ ), un rééquilibrage sous conditions de faciès à Zéolites et finalement une altération de sub-surface. La cohérence entre les conditions $\mathrm{P}-\mathrm{T}$ du métamorphisme et le gradient géothermique mesuré aujourd'hui démontre que ce métamorphisme témoigne de la circulation des fluides hydrothermaux pendant la construction et le refroidissement de l'arc magmatique des Petites Antilles. L'évolution tectonométamorphique reconnue dans le Complexe Basal nous permet de proposer un modèle conceptuel de transport de la chaleur et des fluides à l'intérieur des niveaux crustaux peu profonds de l'arc volcanique actif de la Guadeloupe.

Mots clés : métamorphisme d'arc / Petites Antilles / Guadeloupe / Complexe Basal / évolution tectonométamorphique / fluides hydrothermaux

\section{Introduction}

Elucidating the structural and mineralogical transformations driven by heat and fluid transfers within the crust of magmatic arcs is an important yet tricky problem. It controls the formation of metal ores, particularly porphyry and epithermal ore deposits, and as well is vital for enabling the exploitation of geothermal resources (Sillitoe and Perelló, 2005; Rowland and Simmons, 2012; Chambefort et al., 2017). Such tectono-metamorphic evolutions have been frequently deciphered within ancient, inactive, magmatic arcs, whereas similar data from present-day active oceanic island volcanic arcs remain scarce, mainly because of bad outcrop conditions (Coombs, 1960; Miyashiro, 1967; Oxburgh and Turcotte, 1970; Ernst, 1973; Brown, 2010; Ducea et al., 2015). In the Lesser Antilles active arc, the Guadeloupe archipelago provides a natural laboratory for studying arc-related tectonic and metamorphic processes, first because Basse-Terre, i.e. the volcanic part of Guadeloupe Island, is entirely volcanic showing a north-south decreasing age gradient of its volcanic phases (Samper et al., 2007, 2009) where the northern part, so-called Basal Complex, consists of the oldest - Pleistocene - eruptive rocks (lava, block \& ash flow tuffites) exposed on the island. Second, located at tropical latitudes, Basse-Terre of Guadeloupe is prone to significant weathering and erosion processes (Dessert et al., 2015) where mechanical and chemical erosion rates of around 1-2 mm/yr are effective (Sak et al., 2010, Lloret et al., 2011; Rad et al., 2013; Ricci et al., 2015a, b). In this context, the Basal Complex is a key target for deciphering the evolution of shallow crustal levels of the Lesser Antilles arc as it exposes the most eroded part of the Basse-Terre volcanic chain, consisting of the basement of the volcanic chain. Within this frame, we investigate the tectono-metamorphic evolution of this exhumed piece of the upper crustal level of the Lesser Antilles volcanic arc. We mapped and characterized the lithologies (geochemistry, geochronology) and the structures (structural and kinematic analysis) of the Basal Complex and propose an updated geological map of this northern area of Basse-Terre. Furthermore, we accurately document its metamorphic evolution by the means of a detailed study of the metamorphic reactions preserved in the exposed lava flows and thermodynamic modeling of the mineralogical equilibrium. This dataset allows us to discuss the heat and fluid transfers in the Lesser Antilles magmatic arc, so as to propose a conceptual scheme of these transfers and their influence on the strain accommodation and metamorphic evolution, in the framework of the shallow crustal level of an active volcanic arc.

\section{Guadeloupe in the Lesser Antilles geological context}

The Lesser Antilles volcanic arc is the consequence of the southwest-directed subduction of the North American plate beneath the Caribbean plate (Hawkesworth and Powell, 1980; Demets et al., 2000, Fig. 1A). Since Eo-Oligocene times, two main magmatic arcs were produced through time with a progressive westward migration from an external to an internal volcanic arc, which is still active today (Briden et al., 1979; Westercamp, 1979; Bouysse et al., 1990; Maury et al., 1990; Dixon et al., 1998; Feuillet et al., 2002; Germa et al., 2011).

The Guadeloupe archipelago is formed by the juxtaposition of two geological systems. To the east, Guadeloupe consists of Grande-Terre, La Désirade, Petite-Terre and Marie-Galante Islands, on which early Pliocene-middle Pleistocene limestones were deposited upon volcanic and/or sedimentary crust (Bouysse and Garrabé, 1984; Andreieff et al., 1987; Bouysse et al., 1993; Cornée et al., 2012; Lardeaux et al., 2013; Münch et al., 2013, 2014). To the west, Guadeloupe is composed of Basse-Terre and Les Saintes Islands, which correspond to the inner active arc (Andreieff et al., 1987; Westercamp, 1988; Carlut et al., 2000; Mathieu et al., 2013; Zami et al., 2014; Verati et al., 2016). Basse-Terre consists of a cluster of volcanic complexes, frequently called "volcanic chains", with from north to south (Samper et al., 2007): the oldest Basal Complex characterized by a 3 to $2 \mathrm{Ma}$ aged volcanism, the Septentrional Chain between 1.8 to $1.1 \mathrm{Ma}$, the Axial Chain active from 1 to $0.4 \mathrm{Ma}$, the Grande Découverte-Trois 


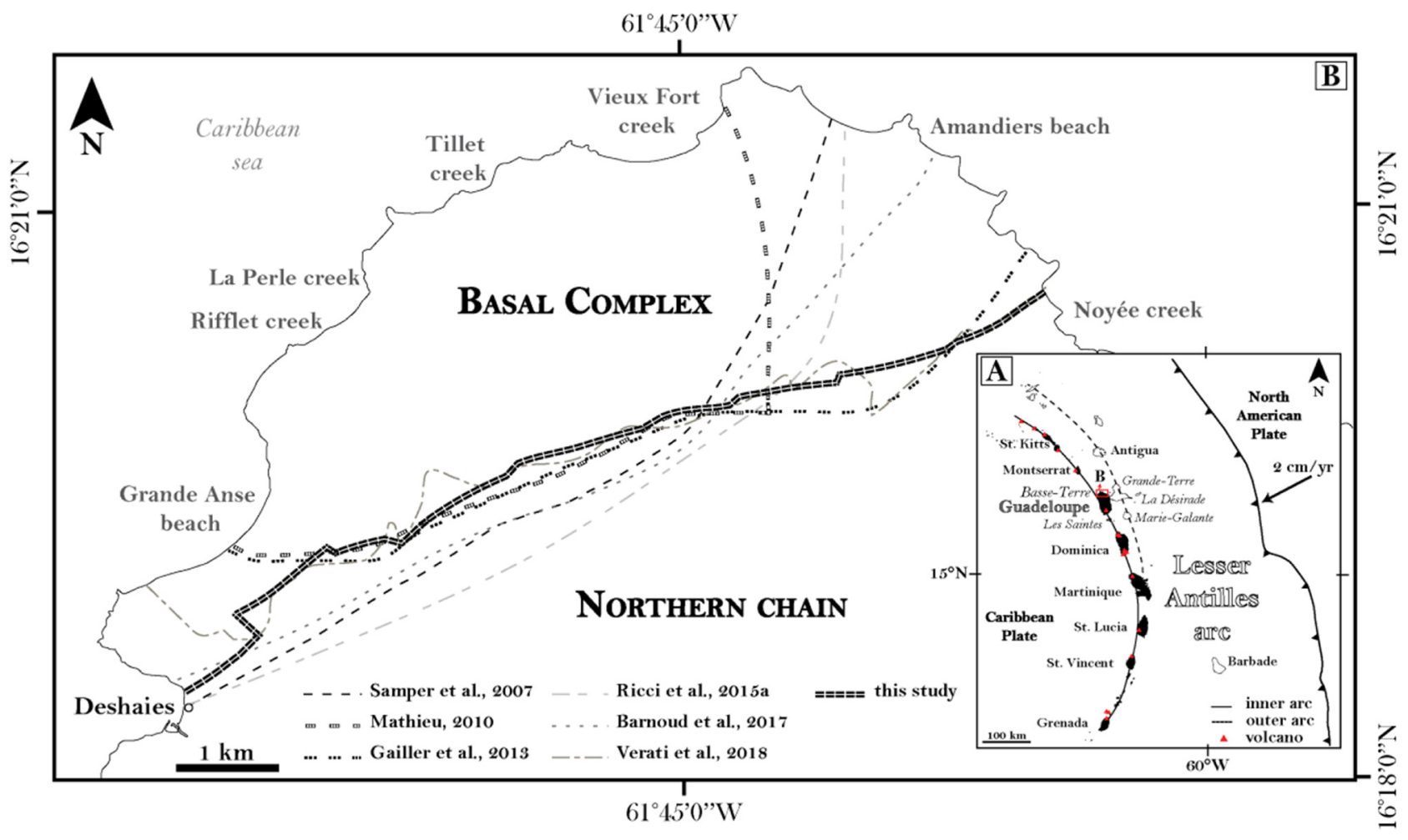

Fig. 1. A: Geodynamic setting of the Lesser Antilles arc (after Feuillet et al., 2001); B: Map of the North of Basse-Terre Island (Guadeloupe) with a review of the several boundaries between the Basal Complex and the Northern Chain proposed in previous studies (Samper et al., 2007; Mathieu, 2010; Gailler et al., 2013; Ricci et al., 2015a; Barnoud et al., 2017; Verati et al., 2018).

Rivières Complex (0.2 Ma-recent) including the present-day active La Soufrière volcano (Boudon et al., 1987, 2008), and the Monts Caraïbes Chain built at around 0.6-0.4 Ma (Blanc, 1983; Ricci et al., 2017).

Several authors have focused their petrographic and geochemical studies on fresh volcanic rocks of the southern active volcanic part of the archipelago, and most of the studies have concentrated further south or near La Soufrière volcano or Bouillante geothermal field providing a revision of the ages of the volcanic formations and the lithological contours (Brown et al., 1977; Dagain, 1981; Blanc, 1983; Boudon et al., 1989; Samper et al., 2007, 2009; Patrier et al., 2013; Verati et al., 2014; Ricci et al., 2017). A recent study has shown the evolution of petrophysical properties from fresh to hydrothermalized volcanic rocks in the volcanic island of Guadeloupe archipelago (Navelot et al., 2018).

However, in the northern part of Basse-Terre, the Basal Complex is exposed and consists of strongly weathered volcanic formations (Mathieu et al., 2013). It has not been remapped since the late sixties (De Reynal de Saint-Michel, 1966), as mapping such area, where exposures are scarce and the vegetal coverage is dense, is challenging. Geophysical investigations provide a regional image of the Basal Complex appearing as the volcanic basement on which the younger volcanic systems have been emplaced (Gailler et al., 2013). Moreover, regional low-grade metamorphism and associated deformation has recently been evidenced in this complex (Verati et al., 2018). Although there is a general agreement to consider Basse-Terre as a cluster of volcanic complexes that become progressively younger southward, the identified boundary between the Basal Complex and the Northern Chain varies depending on previous studies and their interpretation of mapping (Westercamp and Tazieff, 1980; Blanc, 1983; Bouysse et al., 1990; Maury et al., 1990; Samper et al., 2007; Gailler et al., 2013). This limit is difficult to determine because exposure of outcrops is limited in northern BasseTerre. Moreover, near the coastline, the attribution of the Deshaies eroded dome (so called "Gros Morne") either to the Basal Complex or to the Northern Chain remains a topic of debate (Samper et al., 2007; Mathieu, 2010; Gailler et al., 2013; Ricci et al., 2015a; Barnoud et al., 2017; Verati et al., 2018; Fig. 1B). Thus, in order to overcome this ambiguity, we have investigated the age of this dome by the use of ${ }^{40} \mathrm{Ar} /{ }^{39} \mathrm{Ar}$ geochronology.

\section{Material and methods}

\subsection{Mapping lithologies and structures}

With this study, we improve the geological knowledge of the Basal Complex by mapping accurately this volcanic unit, we have distinguished the following formations (see Sect. 3.1 for a detailed description of the lithology):

- often very thick soils, which occupy a significant part (more than 50\%) of the mapping area;

- superficial quaternary sedimentary formations;

- debris flows;

- lava flows. 
This study presents a structural data set consisting of about 230 measurements of bedding, fractures, faults, schistosity, and kinematic criteria acquired over 12 sites across the North of Basse-Terre Island.

These data have allowed us to refine the map of this area, based on previous authors (De Reynal de Saint-Michel, 1966; Dagain et al., 1981).

\subsection{Paleo stress tensors}

We have inversed fault kinematics with the right dihedron method to obtain the paleo-stress tensor using WinTensor software (Angelier and Mechler, 1977; Angelier, 1979; Delvaux and Sperner, 2003). WinTensor allows rotational optimization of the obtained tensor by performing iterative tests of tensors in order to minimize a misfit function (Delvaux and Sperner, 2003). We have performed these inversions with a dataset consisting of fault strikes, dips, plunges of the striae and kinematic criteria. For consistency, a minimum of four structural measurements (faults direction and dip, pitch and kinematics) is needed to obtain a robust paleotensor. The quality of inversion is given by QRw (world stress map quality criteria) ranging from A (very good) to $\mathrm{E}$ (poor quality) depending of the amount of data use for the inversion $(n)$, the ratio between the amount of data used for the inversion over the amount of input data $(n / n t)$, deviation between observed and theoretical slip direction $\left(\alpha_{w}\right)$, the sense of slip confidence level $\left(\mathrm{Cl}_{w}\right)$ and the type of structure (fault, fracture, shear zone). The tensor quality is given by $\mathrm{QRt}$, ranging from $\mathrm{A}$ (very good) to $\mathrm{E}$ (poor quality) and depending on QRw and the dispersion of the measured structures: more dispersed are the data, better is the quality Delvaux and Sperner (2003) (reported in the supplementary data in Appendix Tab. A1).

\subsection{Geochronology}

Grains of plagioclase were extracted from one fresh dacite lava flow sampled north of Deshaies. After magnetic separation (Frantz separator), approximately 200 grains aliquots of limpid plagioclase crystals $(160-500 \mu \mathrm{m})$ were handpicked under a binocular microscope and were repeatedly ultrasonically cleaned in $2 \mathrm{~N} \mathrm{HNO}_{3}$ and then in distilled water and methanol for a few minutes.

The samples were packed in aluminum foil for irradiation in the core of the Triga Mark II nuclear reactor of Pavia (Italy) with several aliquots of sanidine from Taylor Creek Rhyolite (TCR standard, 28.619 $\pm 0.034 \mathrm{Ma}$ in Renne et al., 2010) as a flux monitor. The argon isotopic interferences on $\mathrm{K}$ and $\mathrm{Ca}$ were determined by the irradiation of $\mathrm{KF}$ and $\mathrm{CaF}_{2}$ pure salts from which the following correction factors were obtained: $\left({ }^{40} \mathrm{Ar} /{ }^{39} \mathrm{Ar}\right)_{\mathrm{K}}=969 \times 10^{-3} \pm 3.6 \times 10^{-5}$ at $1 \sigma, \quad\left({ }^{38} \mathrm{Ar} /{ }^{39} \mathrm{Ar}\right)$ $\mathrm{K}=1297 \times 10^{-2} \pm 4.5 \times 10^{-4}$ at $1 \sigma,\left({ }^{39} \mathrm{Ar} /{ }^{37} \mathrm{Ar}\right) \mathrm{Ca}=7.27$ $\times 10^{-4} \pm 4.0 \times 10^{-5}$ at $1 \sigma$, and $\left({ }^{36} \mathrm{Ar} /{ }^{37} \mathrm{Ar}\right) \mathrm{Ca}=2.88 \times 10^{-4}$ $\pm 1.6 \times 10^{-5}$ at $1 \sigma .{ }^{40} \mathrm{Ar} /{ }^{39} \mathrm{Ar}$ step heating analyses were performed at Geosciences Montpellier (France). The gas extraction and purification lines consist of (a) an $\mathrm{IRCO}_{2}$ laser of $100 \mathrm{kHz}$ used at 3-20\% power to heat the samples during $180 \mathrm{~s}$, (b) a lens system for beam focusing, (c) a steel chamber, maintained at $10^{-8}-10^{-9}$ bar, and (d) two $\mathrm{Zr}-\mathrm{Al}$ getters for the purification of the gases. The argon isotopes were analyzed with ARGUS VI multicollector mass spectrometer. The mass discrimination was monitored daily using an automated air pipette and provided a mean value of $0.996817 \pm 0.0013(1 \sigma)$ per dalton. Blank analyses were performed every three sample step. The raw data of each step and blank were processed, and the ages were calculated using the ArArCALC software (Koppers, 2002). Dating parameters (typical blank values, irradiation parameters and $\mathrm{Ar}-\mathrm{Ar}$ analytical details) are reported in the supplementary data in Appendix (Tab. A2). The criteria for defining plateau ages are as follows: (1) Plateau steps should contain at least $50 \%$ of released ${ }^{39} \mathrm{Ar}$, (2) there should be at least three successive steps in the plateau, and (3) the integrated age of the plateau should be in agreement with each apparent age of the plateau within a $2 \sigma$ confidence interval.

\subsection{Geochemistry and petrology}

In order to improve the definition of the lithotypes proposed on the geological map, the magmatic characters of the lavas flows were established. Whole rock major and trace element analyses were thus realized on several samples (analytical results are provided in the supplementary data in Appendix Tabs. A3 and A4). We carefully selected the rock exposure to ensure that the main types of lava flows were sampled. We analysed rock powders by Inductively Coupled Plasma Atomic Emission Spectrometry (ICP-AES) and Inductively Coupled Mass Spectrometry (ICP-MS), for major and trace elements respectively, at the Geochemical and Petrographical Research Center in Nancy (SARM laboratory, CNRS-CRPG, with the procedure proposed by Carignan et al., 2001).

In order to constrain and quantify the petrological evolution of the Basal Complex, we investigated 80 thin sections. Mineral chemistry data were achieved by both electron microprobe analyses and diffractometry (system XPert-Pro MPD, Bragg Brentano geometry, $\mathrm{Cu}$ anticathode, KAlpha1 and KAlpha2 rays, PIXcel detector at the CEMEF in Sophia-Antipolis Scientific Center). Major elements analyses were performed at the "Service Commun de Microsonde" at Montpellier University on a Cameca-SX100 electron microprobe. The operating conditions were a $20 \mathrm{kV}$ accelerating voltage and $10 \mathrm{nA}$ beam current. The chemical analyses of the metamorphic phases are presented in the supplementary data in Appendix Table A5 (Schumacher, 1997).

We also used Raman spectrometry to complete mineral determination (in the supplementary data, Appendix A). The spectra were recorded with a LabRam HR800UV JobinYvon ${ }^{\mathrm{TM}}$ microspectrometer equipped with $1800 \mathrm{~g} / \mathrm{mm}$ gratings and using $532 \mathrm{~nm}$ green laser excitation; acquisition time-span varied from 20 to $70 \mathrm{~s}$ during three accumulating cycles.

\section{Revisiting the geology of the Basal Complex: Towards an updated geological map}

\subsection{Geological formations}

\subsubsection{Superficial formations}

The Basal Complex is only found in the northern Basse-Terre, where the soils consist of vertisols, i.e. typical of old weathered volcanic rocks, with high kaolinite and 


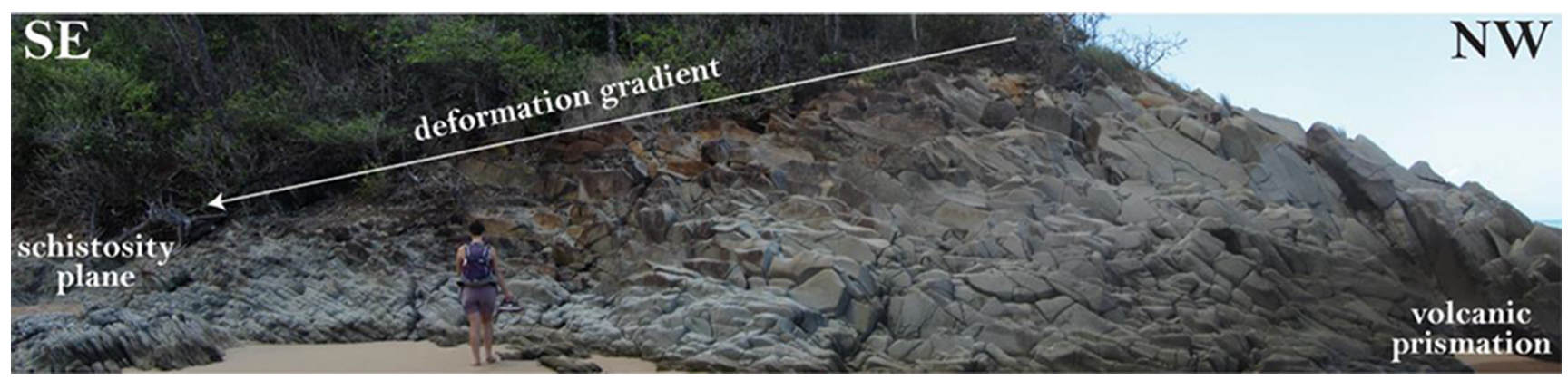

Fig. 2. Volcanic prismation in a rhyodacites lava flow East of Tillet creek, which progressively evolves into a schistosity plane.
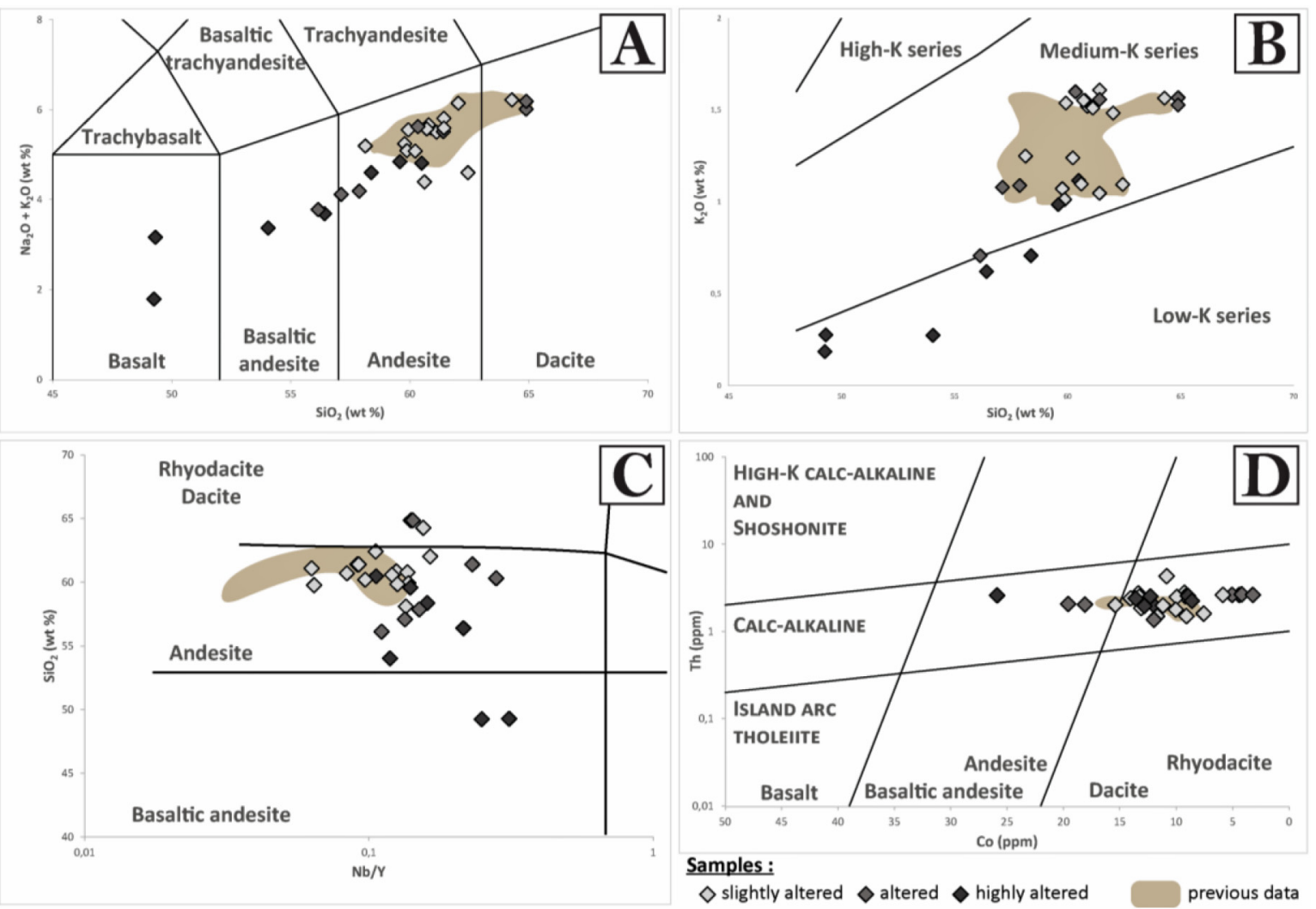

Fig. 3. Geochemical characterization of lava flows. A: Total alkali vs. silica diagram after Bas et al. (1986), previous data from: Samper et al. (2007), Ricci et al. (2017) and Navelot et al. (2018); B: $\mathrm{SiO}_{2}$ vs. $\mathrm{K}_{2} \mathrm{O}$ plot after Peccerillo and Taylor (1976), previous data from Samper et al. (2007, 2009), Ricci et al. (2017) and Navelot et al. (2018); C: $\mathrm{SiO}_{2}$ vs. Nb/Y diagram after Winchester and Floyd (1977), previous data from Ricci et al. (2017); D: Co vs. Th plot after Hastie et al. (2007), previous data from Ricci et al. (2017).

montmorillonite contents (see Dessert et al., 2015 for a review). The superficial sedimentary formations consist of detrital deposits and alluviums. The debris flow deposits, interbedded with lava flows, contain blocks of contrasted sizes varying ranging between centimeter to meter of andesites and dacites as well as varicolored clay aggregates. In a restricted number of places, volcano-clastic deposits are interlayered within debris flows.

\subsubsection{Lavas flows}

Lavas flows are easily observable along the coastline, and they extend inland up to 100 to $150 \mathrm{~m}$ above sea level, while eroded volcanic pitons and domes of 200 to $300 \mathrm{~m}$ high are still recognizable in the landscape. Along the coastal exposures, rocks show porphyric textures with different abundances (30 $60 \%$ ), of plagioclases, pyroxenes and/or oxydes phenocrysts. Columnar jointing of andesite and dacite lavas flows is a common volcanic structure that can be recognized at the regional scale. Lithological interfaces, stratigraphy or $\mathrm{S}_{0}$, are easily observable within sequences of alternating lava flows and pyroclastic deposits. Lava flows fabrics, particularly well expressed in dacites and rhyodacites, precisely prismation (Fig. 2) and magmatic fluidality are also typical examples of primary volcanic structures.

In the Total Alkali versus Silica (TAS) diagram (Bas et al., 1986; Fig. 3A) $\mathrm{SiO}_{2}$ contents range from 49 to $65 \mathrm{wt} . \%$ for lava flows and our sample's compositions evolve from basalt to dacite. In the $\mathrm{K}_{2} \mathrm{O}$ versus $\mathrm{SiO}_{2}$ diagram (Peccerillo and Taylor, 

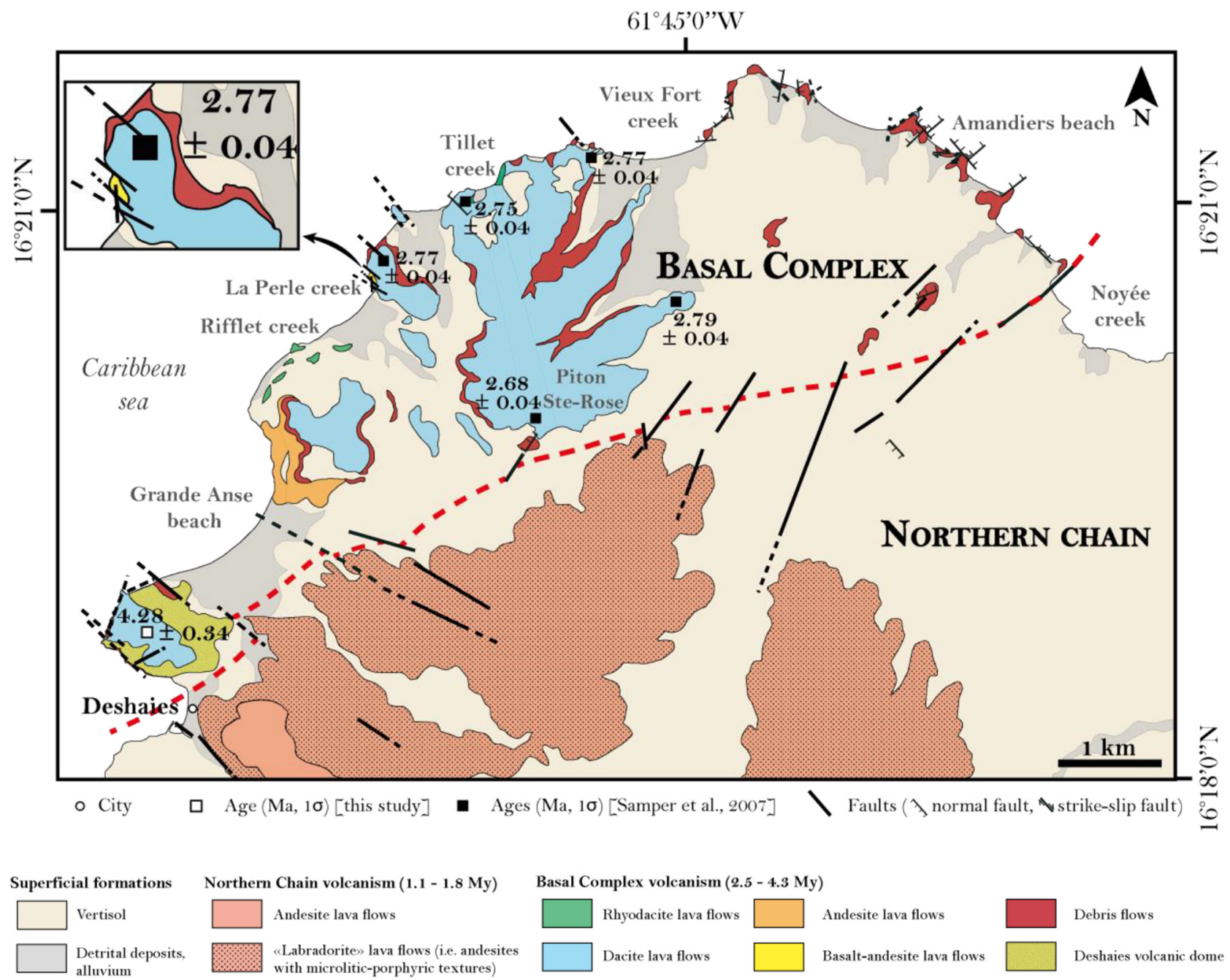

Fig. 4. Geological map of the North of Basse-Terre Island (modified after De Reynal de Saint-Michel, 1966), showing the main lithologies and geochemical affinities of volcanic rocks.

1976 for arc volcanic lavas; Fig. 3B), the studied lavas fall within the fields of Median-K to Low-K series. In the $\mathrm{SiO}_{2}$ versus $\mathrm{Nb} / \mathrm{Y}$ diagram (Winchester and Floyd, 1977; Fig. 3C), the studied samples belong to the calc-alkaline serie of basaltic-andesite to dacite. All together, these diagrams, classically used to define the chemical composition of volcanic rocks, show that the majority of the samples are andesites.

However, major and some trace elements, mainly Large Ion Lithophile Element (LILE) and Light Rare Earth Element (LREE), are severely mobile in weathered and/or hydrothermally altered lavas. Therefore, to improve the geochemical characterization of our samples, we selected diagrams based only on minor and trace elements considered as being the most immobile. Samples where LOI (loss on ignition) is below 1$2 \%$, demonstrating that weathering is insignificant, are named "slightly altered" while samples with LOI above $3 \%$, evidencing alteration, are named "altered" to "highly altered". The $\mathrm{Zr} / \mathrm{Ti}-\mathrm{Nb} / \mathrm{Y}$ diagram is classically employed for recognizing rock types even in altered rocks (Winchester and Floyd, 1977; Pearce, 1996), but in tropical regions due to extreme chemical weathering conditions, even $\mathrm{Ti}$ and $\mathrm{Zr}$ are mobile (Braun et al., 1993, 2005; Melfi et al., 1996; Nahon and Merino, 1996; Cornu et al., 1999; Ma et al., 2007). We therefore used the Th-Co diagram proposed by Hastie et al. (2007) for altered arc volcanic rocks, and in this diagram the studied rocks show typical characters of calc-alkaline volcanic series (Fig. 3D). Our samples, basaltic andesite to rhyodacite, thus followed a differentiated serie. All together, these geochemical data indicate that the Basal Complex lavas belong to the Medium K calc-alkaline series with the following more or less differentiated types: basaltic-andesites, andesites, dacites and rhyodacites. We used therefore this nomenclature in the proposed updated geological map (Fig. 4).

Moreover, we also used trace elements diagrams to compare our results to data from other volcanic rocks in BasseTerre, as well as results obtained on the fresh rocks of the Basal Complex (Samper et al., 2007). The Rare-Earth-Element (REE) diagrams normalized to chondrite values (after Sun and McDonough, 1989; Fig. 5A) display relatively constant slopes, with small enrichment in Light REE (LREE) for most samples, typical for subduction related calc-alkaline REE chondrite-normalized patterns. The multi-element diagrams of 

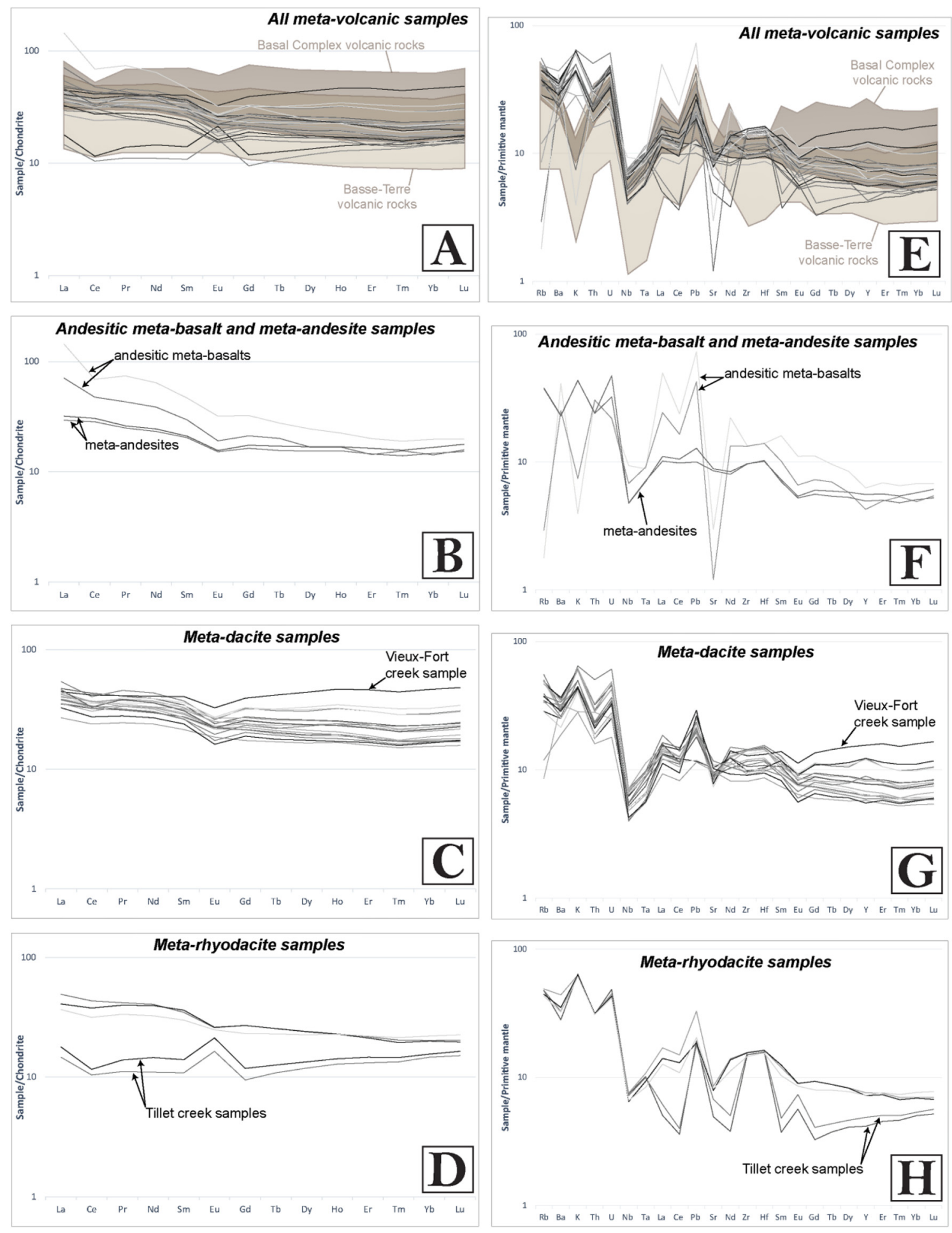

Fig. 5. A-D: Rare Earth Element (REE) patterns normalized to chondrite values (after Sun and McDonough, 1989) of the samples used in this study; E-H: Multi-element patterns normalized to primitive-mantle (after Sun and McDonough, 1989) for the same samples as in Figures 4A4D. The shaded bands correspond to the range determined for volcanic rocks of the whole Basse-Terre and the Basal Complex (from Blanc, 1983; Samper et al., 2007; Ricci et al., 2017).

incompatible elements normalized to primitive mantle (Sun and McDonough, 1989; Fig. 5E) display patterns typical of arc lavas, with $\mathrm{Pb}, \mathrm{U}$ and Large Ion Lithophile Element (LILE) enrichments, and also $\mathrm{Nb}$ and Ta depletions (Labanieh, 2009).
In andesitic meta-basalts (Fig. 5B), samples display first significant HREE depleted patterns (with 80 to 110 times chondritic abundances for LREE and 20 times chondritic abundances for HREE), typically described after extensive 
weathering (Ma et al., 2007) and second slightly negative Eu anomaly which may be interpreted as plagioclase fractionation (Taylor and McLennan, 1995) or as hydrothermal alteration under mildly acidic low-temperature solutions. Finally, the multi-elements diagrams (Fig. 5F) show a strong Rb, Sr and K depletion, indicating the influence of surface alteration processes (Patino et al., 2003).

In meta-andesites (Fig. 5B), the observed patterns displays slightly LREE enrichment, and positives $\mathrm{Eu}, \mathrm{Ce}$ and $\mathrm{Gd}$ anomalies attest for intense weathering (Ma et al., 2007). However, it has also been demonstrated that strong hydrothermal alteration may also lead to positive anomaly of $\mathrm{Ce}$.

In meta-dacites (Fig. 5C), the observed trends display a flat-type or a very slight LREE enrichment with negative Ce anomaly for a few samples. This feature is interpreted as a post-magmatic process due to surface alteration processes under tropical weathering conditions (Cotten et al., 1995; Samper et al., 2009; Ricci et al., 2017). A sample from VieuxFort creek (BT5 01) shows LREE depletion and negative Eu anomaly reflecting high-temperature alteration under mildly acidic conditions (Bau, 1991). In multi-elements diagrams (Fig. 5G), our patterns are comparable to those previously described for the Basal Complex. Several samples show positive $\mathrm{Y}$ anomaly, in relation with surface alteration processes, specifically under tropical climates (Cotten et al., 1995; Labanieh, 2009).

In meta-rhyodacites (Fig. 5D), two types of trends can be highlighted. A first one, similar to the patterns previously recognized for the same lavas within the Basal Complex patterns. A second pattern, observed for Tillet creek samples (BT9_01-02), displays a flat-type trend with negative $\mathrm{Ce}$ and large positive $\mathrm{Eu}$ anomalies. This likely result from rock interaction with acidic high-temperature hydrothermal fluids (Michard et al., 1983; Michard, 1989; Cotten et al., 1995). Multi-elements diagrams also show two different patterns (Fig. $5 \mathrm{H}$ ), both with $\mathrm{Zr}-\mathrm{Hf}$ positive anomalies. If the first one is similar to the trends depicted in the Basal Complex volcanic rocks, another one characterizes the samples with strong negative $\mathrm{La}-\mathrm{Ce}$ anomalies, negative $\mathrm{Sr}-\mathrm{Nd}$ anomalies and always a large Eu anomaly.

All together, these data demonstrate that the volcanic rocks of the Basal Complex were severely transformed after their crystallization in relation with hydrothermal fluid circulations and supergene alterations.

Fortunately, even in significantly altered volcanic rocks, the primary volcanic mineralogy is, at least partly preserved, allowing the mineralogy of the mapped formations to be characterized. From a mineralogical point of view, the basaltic andesites and andesites display a volcanic primary association with phenocrysts of mafic plagioclase, clinopyroxene and ilmenite and/or titanomagnetite, in a decreasing order of abundance. Groundmass is typically microlitic and oxide-rich. In the andesites, the primary volcanic mineralogy is an association of phenocrysts of plagioclase, clinopyroxene, orthopyroxene and ilmenite, with rare amphiboles. The groundmass is characterized by the great quantity of microlites of plagioclase and oxides. Dacites and rhyodacites are composed of phenocrysts of plagioclase, orthopyroxene, clinopyroxene, ilmenite and quartz, while the groundmass is rich in quartz, plagioclase, oxides and anorthoclase microlites.

\subsection{Structure and strain pattern}

At a regional scale, lithological interfaces and lava flows fabrics are oriented in two main directions $\mathrm{N} 160^{\circ}-170^{\circ}$ and $\mathrm{N} 20^{\circ}-30^{\circ}$, moderately dipping between $4^{\circ}$ and $44^{\circ}$, with a mean dip of $20^{\circ}$ towards West (Legendre, 2018)(Fig. 6B). Primary magmatic structures are overprinted by secondary tectonic structures. We identify three types of tectonic structures that developed during the progressive cooling of this volcanic complex through time and classify these as ductile structures, structures developed at the brittle-ductile transition and brittle structures.

\subsubsection{Ductile strain}

At a mesoscopic scale the tectonic fabric is defined by smooth parallel cleavage areas separated by centimeter-scale undeformed zones (i.e. microlithons). Because cleavages are frequently interrupted at the scale of the outcrop (Fig. 7A), this tectonic fabric corresponds to pervasive disjunctive spaced cleavages (Powell, 1979; Passchier and Trouw, 2005). Spaced cleavage stripes (in the sense of Beach, 1982) are common and appear yellow-greenish to pink, with respect to the volcanic matrix, because of the crystallization of secondary minerals (Fig. 7). In some cases, the cleavage stripes turn into stylolithic joints (Fig. 7B). Moreover, seams are underlined by insoluble residues as well as volcanic enclaves (Fig. 7C) truncated by disjunctive schistosity planes (Fig. 7D), representing evidences for a pressure-solution processes driven strain (Fig. 7E; Rutter, 1976; Beach, 1979). Networks of quartz, albite, pyrite or calcite bearing veins frequently interconnect the schistosity planes. This geometry is comparable to the one described when dilatant micro-faults occur in jointed cohesive rocks (Kettermann et al., 2016). Thin sections also show that dissolution of phenocrysts is underlined by the development of dark and pink seams of insoluble minerals (Fig. 7F), mainly fine-grained Feoxides, at the grain boundaries. Regional finite strain pattern displays localized schistose domains surrounding lenses of undeformed country rocks (Fig. 2), preserving primary magmatic structures. Structural mapping evidences moderately dipping schistosity planes with a $\mathrm{N} 80^{\circ}-100^{\circ}$ main direction (Fig. 6A).

\subsubsection{Brittle-ductile strain}

In a specific area, north of La Perle creek, we have identified "hydrothermal tectonic breccias" (Sibson, 1977; Jébrak, 1997; Woodcock and Mort, 2008). Along steeply dipping fault planes we observed textures of fragmentation containing large fragments of volcanic rocks. More than $60 \%$ of the fragments are larger than $2 \mathrm{~cm}$ in diameter giving rise to "mosaic breccias" according to the classifications of Jébrak (1997) or Woodcock and Mort (2008). These volcanic rocks fragments are cemented in a fine-grained matrix entirely composed of hydrothermal and strongly altered minerals. Thus these breccias are cohesive following Sibson's (1977) textural classification. Most of the fragments are angular (Fig. 8B), a common feature for fluid assisted brecciation. However, some fragments, generally small-sized, are more rounded due to local dissolution processes (Fig. 8A). In a few cases, the spaced volcanic fragments are oriented parallel to the observed fault planes. All together, these features are compatible with 


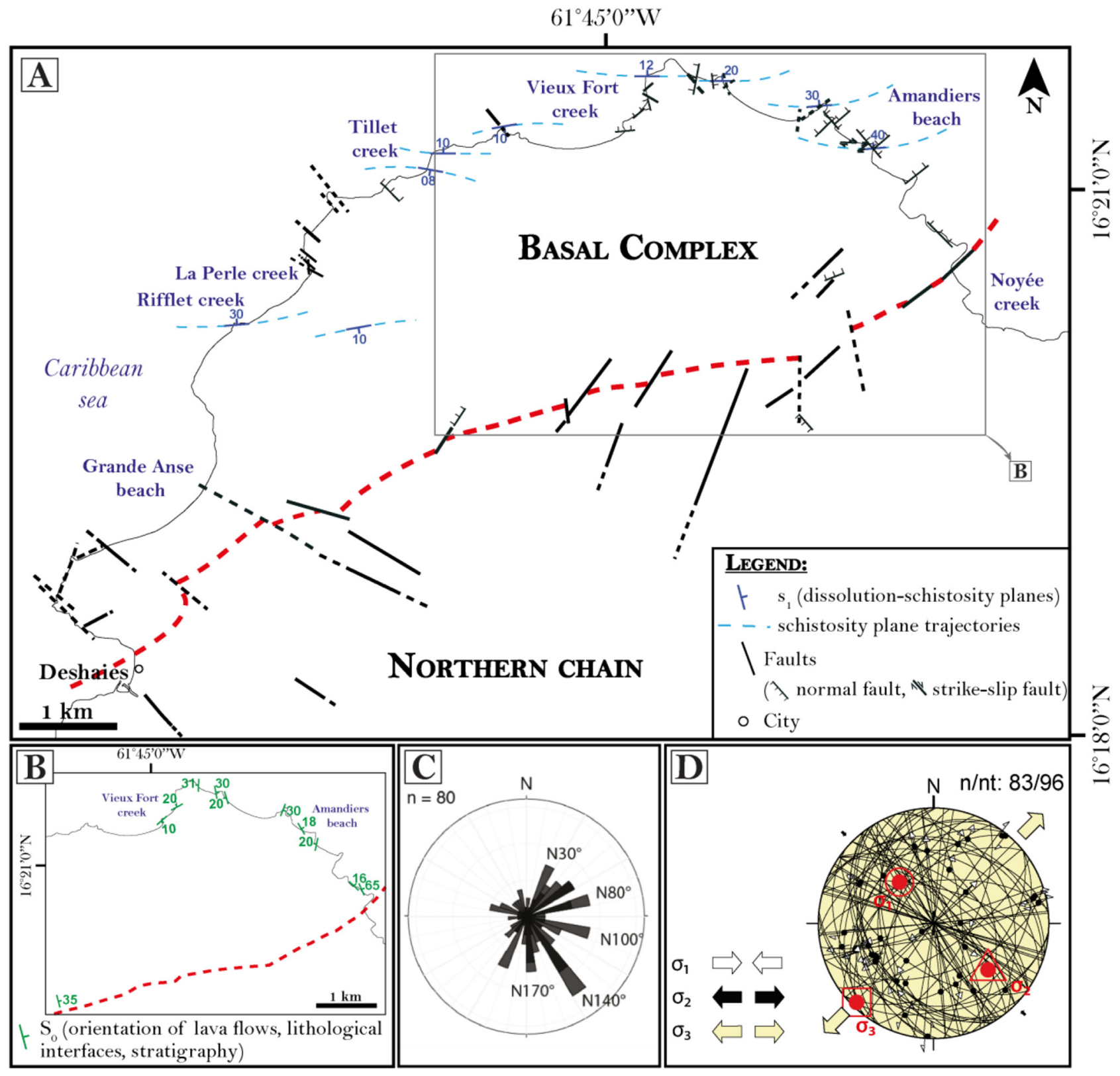

Fig. 6. A: Tectonic sketch map of the North of Basse-Terre where the main faults observed are reported with measures of the dissolutionschistosity planes and the extension of their trajectories. The red dotted line indicates the boundary between the volcanic complexes of the Basal Complex and the Northern Chain; B: Simplified map of the orientations of lava flows and horizons surface $\left(\mathrm{S}_{0}\right)$; $\mathrm{C}$ : Rose diagram displaying the faults measured in the Basal Complex; D: Paleotensor obtained by inversion of field data (faults with kinematics criteria, fractures).

deformation processes developed at the brittle to ductile transition. These hydrothermal tectonic breccias occur under two aspects that are easy to identify in the field by their colour: (1) red, within which some volcanic clasts are partly preserved in the core of hydrothermal secondary minerals (Figs. 8A, 8C and $8 \mathrm{D})$, (2) yellow-green within which volcanic clasts are only phantoms replaced by clay minerals indicating an almost complete supergene alteration of the whole hydrothermal mineralogy (Figs. 8A-8C). Besides this difference in the degree of supergene alteration, these breccias show differences of orientation and two major directions were highlighted (Fig. 8E): N110-N140 and N160-N10.

\subsubsection{Brittle strain}

The Basal Complex is also affected by brittle structures. The four families of regional directions are represented on the mapped area (Fig. 6A), with a main dominant fault family of N140-N150 (Fig. 6C) and with centimetrical offsets. Tectoglyphs along fault planes show normal dip-slip to oblique slip kinematics at all measurements sites, except at one locality where the offset of an andesitic pebble shows an apparent inverse kinematics, although the fault plane does not display any kinematic indications. At each site and although kinematics indicators were scarce, giving weak inversion data 

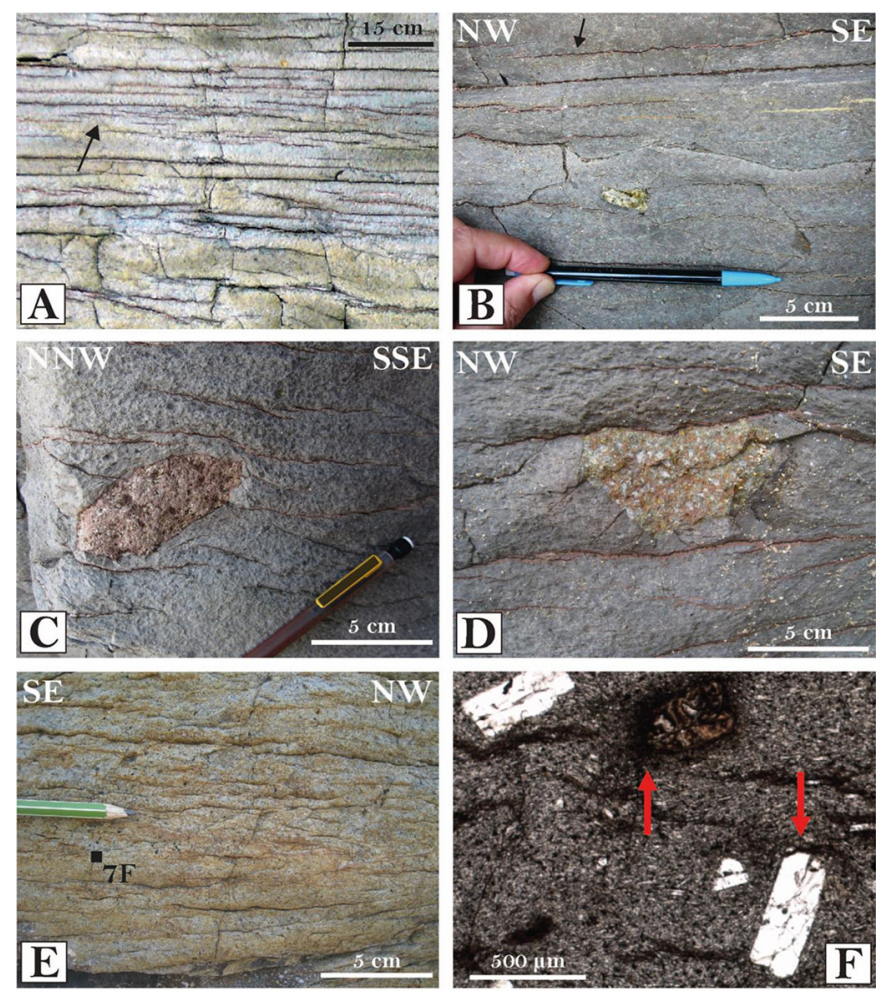

Fig. 7. A: Discrete and spaced cleavages, frequently interrupted at the outcrop scale, underlined by pink and dark seams of insoluble minerals in a meta-rhyodacite lava flow (western part of Tillet creek); B: Dissolution-schistosity plane underlined by insoluble minerals where cleavage becomes a stylolithic joints in a meta-rhyodacite lava flow from Tillet creek; C: Volcanic enclave in the core of pervasive disjunctive spaced cleavages in a meta-rhyodacite deposit from Tillet creek; D: Dissolution-schistosity planes and truncated volcanic enclave in a meta-rhyodacite deposit from Tillet creek; E: Disjunctive schistosity planes highlighting pressure-solution seams in a metarhyodacite lava flow from Rifflet creek. The black square indicates the location of the sample in Figure 7E; F: Photomicrographs of microstructures from schistose zones observed in thin sections using polarized and cross-polarized microscopy. Schistosity is underlined by oxides in a meta-rhyodacite lava flow from Rifflet creek. Red arrows highlight microstructures of dissolution at the grain boundary of a meta-pyroxene and a plagioclase volcanic phenocryst.

at individual sites, paleostress inversion shows a $\sigma_{3}$ trending NE-SW and NW-SE along $\mathrm{N} 50^{\circ}$ and $\mathrm{N} 150^{\circ}$ trending faults, respectively. Inversion of the whole dataset provides a pureextensional stress regime with $\sigma_{3}$ trending NE-SW (Fig. 6D).

The trend of the southern boundary of the Basal Complex is a lineament at $\mathrm{N} 50^{\circ}$ defined by a series of $\mathrm{N} 150^{\circ}$ and $\mathrm{N} 50^{\circ}$ faults, showing the same relationship with $\mathrm{N} 150^{\circ}$ crosscutting $\mathrm{N} 50^{\circ}$ faults.

\subsection{Southern boundary of the Basal Complex}

The two plagioclase aliquots from the sampled dacite (aliquots A and B, Fig. 9, Tab. 1, Tab. A2) yield two concordant plateau ages of $4.10 \pm 1.03 \mathrm{Ma}\left(91.36 \%\right.$ of ${ }^{39} \mathrm{Ar}$ released, $\mathrm{MSWD}=0.49)$ and $4.42 \pm 0.91 \mathrm{Ma}\left(86.67 \%\right.$ of ${ }^{39} \mathrm{Ar}$

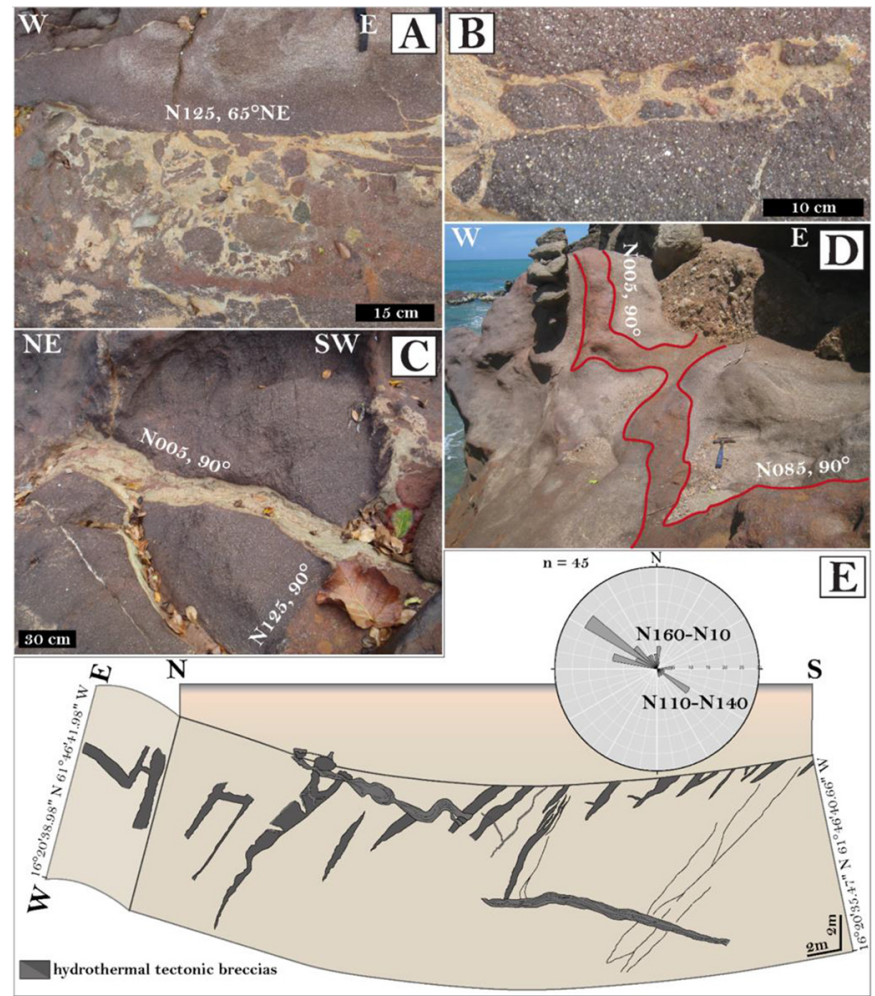

Fig. 8. Several structures of hydrothermal tectonic breccias from $\mathrm{La}$ Perle creek. A: Hydrothermal tectonic breccia with more rounded fragments due to local dissolution processes; B: Hydrothermal tectonic breccia where fragments are angular; C: Yellow-green hydrothermal tectonic breccia cutting a red hydrothermal tectonic breccia, both breccias are meta-dacite; D: Red hydrothermal tectonic breccia of meta-basalt-andesite; E: Schematic representation highlighting two major directions at the scale of the outcrop.

released, $\mathrm{MSWD}=0.51$ ) respectively. The inverse isochron calculations yield ages at $4.05 \pm 1.39 \mathrm{Ma}(\mathrm{MSWD}=0.61$; initial ${ }^{40} \mathrm{Ar} /{ }^{36} \mathrm{Ar}$ ratio at $\left.301.09 \pm 53.47\right)$ and $3.46 \pm 1.92 \mathrm{Ma}$ $\left(\mathrm{MSWD}=0.20\right.$; initial ${ }^{40} \mathrm{Ar} /{ }^{36} \mathrm{Ar}$ ratio at $\left.360.2 \pm 111.0\right)$ respectively. The combination of aliquot analyses yields a plateau age at $4.28 \pm 0.68 \mathrm{Ma}\left(87.89 \%\right.$ of ${ }^{39} \mathrm{Ar}$ released, MSWD $=0.48)$ and an inverse isochron age of $3.97 \pm 1.03 \mathrm{Ma}$ $(\mathrm{MSWD}=0.46)$ with an initial ${ }^{40} \mathrm{Ar} /{ }^{36} \mathrm{Ar}$ ratio at $316.4 \pm 48.4$ indicating that the trapped ${ }^{40} \mathrm{Ar} /{ }^{36} \mathrm{Ar}$ is indistinguishable from atmospheric ${ }^{40} \mathrm{Ar} /{ }^{36} \mathrm{Ar}$ (Lee et al., 2006). However, the uncertainty of the plateau age is relatively high because of important atmospheric ${ }^{40} \mathrm{Ar}$ contribution with respect to radiogenic ${ }^{40} \mathrm{Ar}$ (16 to $81 \%$, see in supplementary data). All single ages are concordant at the $2 \sigma$ level and we retain the combined plateau age of $4.28 \pm 0.68 \mathrm{Ma}$ as the best estimate of the age of the dacite lava flow. This new ${ }^{40} \mathrm{Ar}-{ }^{39} \mathrm{Ar}$ dating demonstrates that the "Gros Morne" dacite dome belongs to the Basal Complex. This Ar-Ar age is older than recent previous obtained $\mathrm{K}-\mathrm{Ar}$ ages for the Basal Complex (Samper et al., 2007). We sampled the Gros Morne volcanic dome located further west than the sampled lava flows dated in Samper et al. (2007) (Fig. 2). Similarly to these authors, we have selected only the rocks that seemed fresh enough in order to minimize the potential impacts of hydrothermalism and 

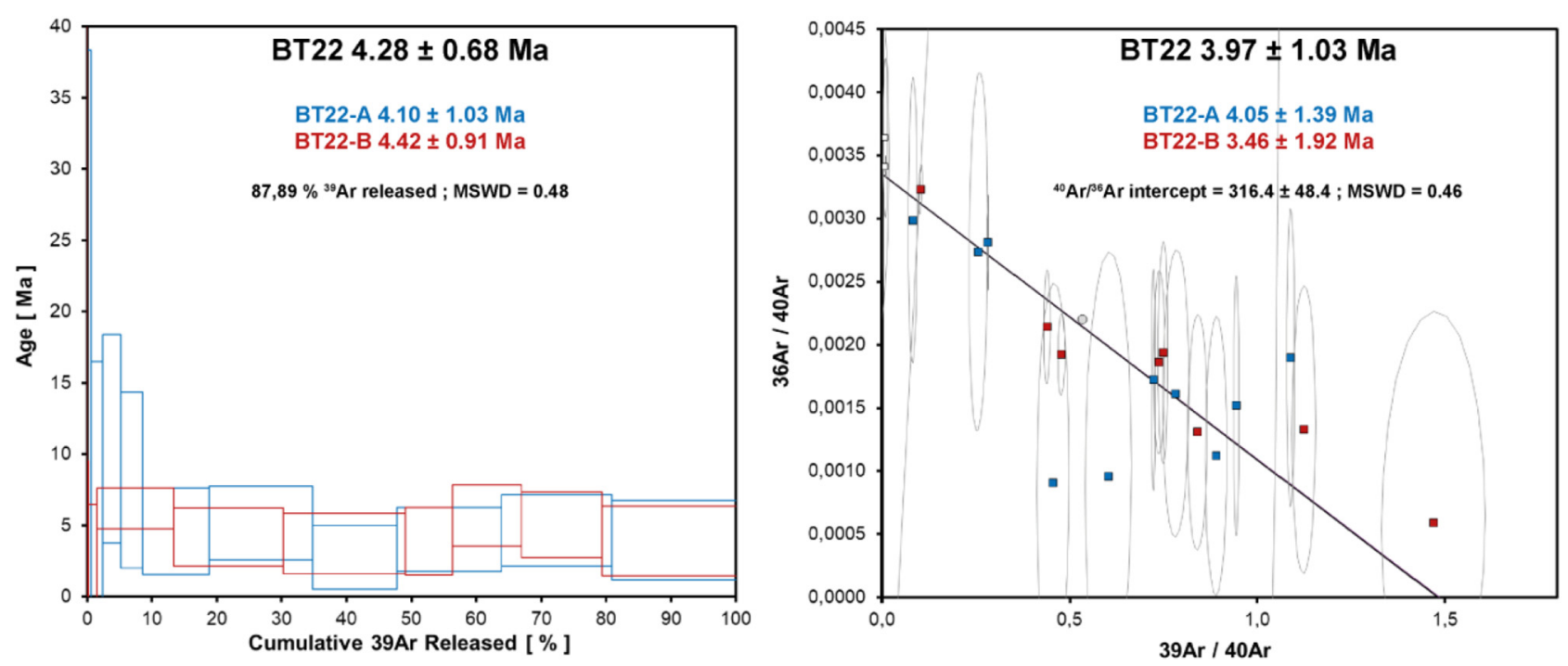

Fig. 9. Uncertainties herein are given at the $2 \sigma$ level. A: ${ }^{40} \mathrm{Ar} /{ }^{39} \mathrm{Ar}$ spectra for BT22-sample from "Gros Morne" dacite dome of Deshaies; B: Inverse isochron for BT22-sample from "Gros Morne" dacite dome of Deshaies. MSWD= Mean Square Weighted Deviation.

Table 1. ${ }^{40} \mathrm{Ar} /{ }^{39} \mathrm{Ar}$ analyses results.

\begin{tabular}{|c|c|c|c|c|c|c|c|c|c|c|c|c|c|c|c|c|}
\hline Sample & Latitude & Longitude & Lithology & $\begin{array}{l}\text { Metarial } \\
\text { dated }\end{array}$ & Analyse & $\begin{array}{l}\text { Plateau } \\
\text { age } \\
\text { (Ma) }\end{array}$ & $\pm 2 \sigma$ & $\begin{array}{l}\%{ }^{39} \mathrm{Ar} \\
\text { released }\end{array}$ & MSWD & $\begin{array}{l}\text { Inverse } \\
\text { isochrone } \\
\text { age }(\mathrm{Ma})\end{array}$ & $\pm 2 \sigma$ & $\begin{array}{l}{ }^{40} \mathrm{Ar} /{ }^{36} \mathrm{Ar} \\
\text { intercept }\end{array}$ & $\pm 2 \sigma$ & MSWD & $\begin{array}{l}\text { Total } \\
\text { fusion } \\
\text { age (Ma) }\end{array}$ & $\pm 2 \sigma$ \\
\hline \multirow{2}{*}{ BT22 } & \multirow{2}{*}{$\begin{array}{l}16^{\circ} 18^{\prime} \\
49.59^{\prime \prime} \mathrm{N}\end{array}$} & \multirow{2}{*}{$\begin{array}{l}61^{\circ} 47^{\prime} \\
47.73^{\prime \prime} \mathrm{W}\end{array}$} & \multirow{2}{*}{$\begin{array}{l}\text { Dacite } \\
\text { lava flow }\end{array}$} & \multirow{2}{*}{ Plagioclase } & B & 4.42 & 0.91 & 86.67 & 0.51 & 3.46 & 1.92 & 360.2 & 111.0 & 0.20 & 4.46 & 0.85 \\
\hline & & & & & $\begin{array}{l}\mathrm{A}+\mathrm{B} \\
\text { combined }\end{array}$ & 4.28 & 0.68 & 87.89 & 0.48 & 3.97 & 1.03 & 316.40 & 24.20 & 0.46 & 4.46 & 0.70 \\
\hline
\end{tabular}

alteration on geochronological results in relation with $\mathrm{K}$ losses and $\mathrm{Ar}$ enrichments. Given that we considered previous $\mathrm{K}-\mathrm{Ar}$ ages as significant, two different volcanic events may have occurred. Taking into account this new chronological constraint, south of the Deshaies dome, the Basal Complex is therefore clearly limited by a series of faults with $\mathrm{N} 150^{\circ}$ and $\mathrm{N} 50^{\circ}$ main directions. Its northeastern limit is also tectonic marked by mainly $\mathrm{N} 50^{\circ}$ oriented faults. Far for the coastline, in areas where outcrops are of bad quality and thus in absence of field observations, a morphological limit, with Basal Complex formations covered by lava flows from the Northern Chain, is not excluded.

\section{Metamorphic evolution of the Basal Complex}

Mineralogical evidences for low-grade metamorphism have been recently discovered in the Basal Complex (Verati et al., 2018), however detailed investigations of the diversity of the mineralogical evolutions observable in the various volcanic lithologies still lack.

Under low-temperature conditions, metamorphic recrystallizations are incomplete and metamorphic phases coexist with metastable magmatic minerals (Frey and Robinson, 1999).
It is the case in the studied rocks, which present systematic textural evidences of such chemical disequilibrium, particularly partial replacement of volcanic phases.

This peculiar metamorphism affects the whole Basal Complex and is identified by the systematic occurrence of post-magmatic reaction phases (Fig. 10).

\subsection{Mineralogical characterization of metamorphic assemblages}

In andesitic meta-basalts (Fig. 11A), secondary minerals are: quartz, albite, chlorite, actinolite, titanite, scarce white micas, prehnite, epidote and calcite. Chlorite occurs as millimeter patches within the groundmass or relicts of magmatic pyroxenes. Actinolite is present as acicular crystals around volcanic clinopyroxenes or in association with chlorites in the groundmass. Titanite is recognized as finegrained brownish aggregates within relicts of plagioclase phenocrysts, while white mica occurs, in association with epidote and quartz, as replacement patches in volcanic phenocrysts. Prehnite occurs as colourless pseudomorphic patches or radially developed aggregates of low relief. These rocks are severely altered resulting in an argilic overprint (significant development of clay minerals) typical of alteration under tropical conditions. 


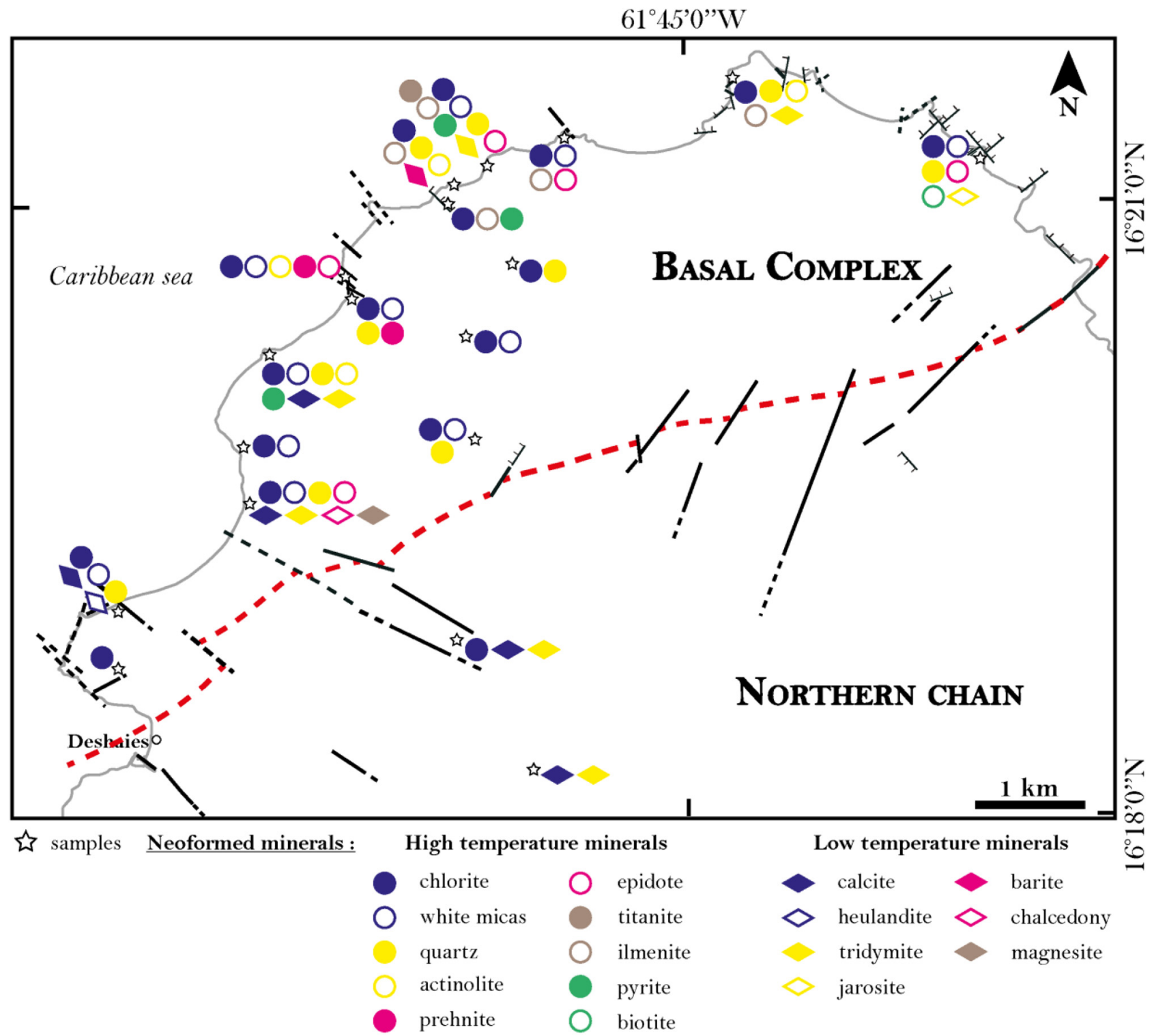

Fig. 10. Distribution of metamorphic phases (high and low temperatures) within the Basal Complex (modified after Verati et al., 2018). Locations of sampling sites are reported with stars.

In meta-andesites, chlorite, actinolite, albite, quartz, white mica, titanite are the ubiquitous metamorphic assemblage accompanied by variably developed epidote and oxides minerals. Chlorite colors range from pale green to various shades of yellow and brown. Actinolite commonly occurs as colorless crystals, sometimes in association with chlorite, at the rims of volcanic clinopyroxenes. Magmatic amphiboles are progressively transformed into a fringe of epitaxial acicular actinolites. Small sized titanite grains are associated with actinolite within reaction rims around pyroxenes. In some samples, coronas of metamorphic albite occur surrounding volcanic plagioclases, while in other rocks plagioclase phenocrysts are partially replaced by albite, white micas and calcite. Millimeter-sized grains of epidote are observable in the volcanic groundmass. Numerous cracks and veinlets are filled by calcite and tridymite (Fig. 12A) \pm quartz \pm albite \pm chlorite. This assemblage must be interpreted as lower temperature assemblage developed during progressing cooling of the meta-andesite. These meta-andesites are also deeply altered giving rise to a typical assemblage of quartz, pyrite, calcite, magnesite, chalcedony (Fig. 12B), gypsum and clays minerals (kaolinite, illite, montmorillonite, smectite).

Comparable to what has been recently proposed by Verati et al. (2018), for meta-dacites (Fig. 11B) and meta-rhyodacites (Fig. 11C), the secondary metamorphic association is: albite, muscovite, chlorite, titanite, quartz, clinozoisite/epidote and ilmenite. White mica appears as irregular pseudomorphic patches, mainly rectangular, and close to quartz veins. We also observed sulphate, like barite, typical for low- temperature conditions and supergene alteration products with clays minerals (smectite and montmorillonite).

In some debris flow, metamorphic assemblages can also be identified (Fig. 11D): chlorite, white micas, quartz, actinolite, epidote, biotite and ilmenite. The meta-debris flows are also 

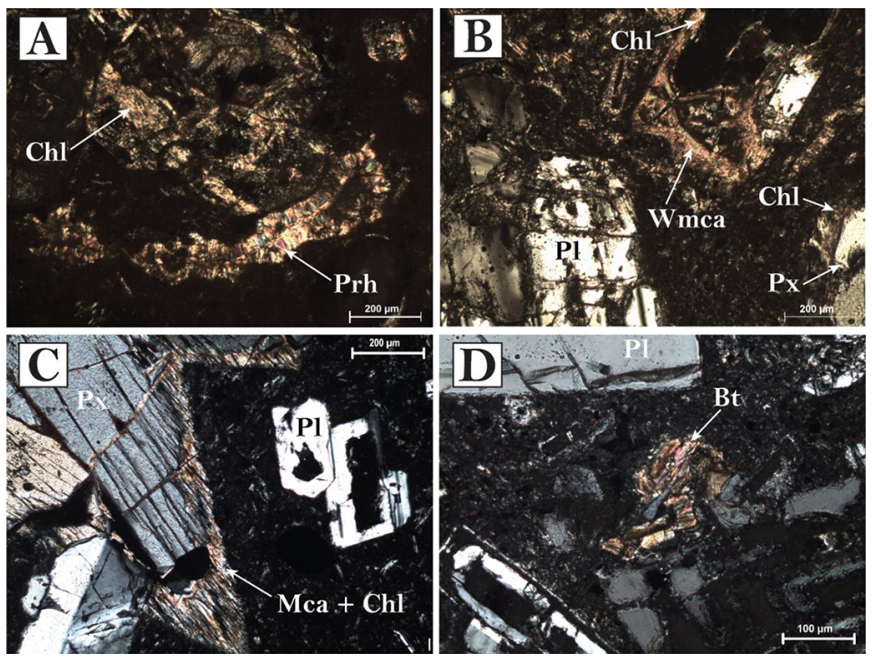

Fig. 11. Photomicrographs of highly metamorphic transformations in PPL. Bt: biotite; Chl: chlorite; Mca: micas; Wmca: white micas; Pl: plagioclase; Prh: prehnite; Px: pyroxene. A: Basalt-andesitic lava flow from La Perle creek (BT13); B: Dacitic lava flow from a dome south of Rifflet (BT17); C: Rhyodacitic lava flow from Rifflet creek (BT16); D: Debris flow from Amandiers beach (BT1).
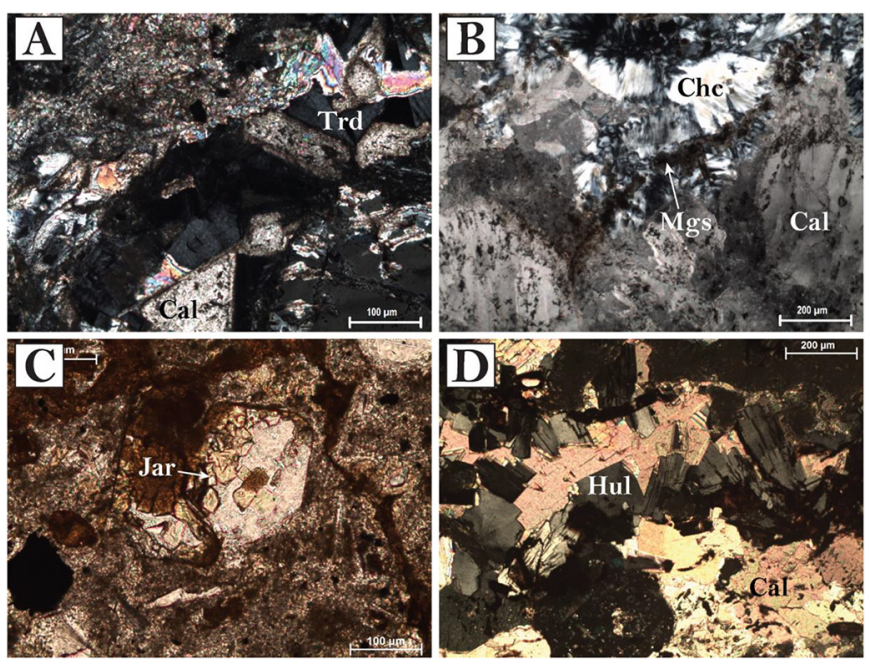

Fig. 12. Photomicrographs of hydrothermal alteration in PPL. Cal: calcite; Chc: chalcedony; Hul: heulandite; Jar: jarosite; Mgs: magnesite; Trd: tridymite. A: Andesitic lava flow from north of Grande-Anse beach (BT19); B: Vein in andesitic lava flow from north of Grande-Anse beach (BT19); C: Debris flow from Amandiers beach (BT1); D: Vein in debris flow from south of Grande-Anse beach, at the bottom of Gros-Morne near Deshaies (BT21).

hydrothermally altered giving rise to a typical assemblage of pyrite, calcite, $\mathrm{SiO}_{2}$ polymorphs (tridymite, chalcedony) and sulphate (jarosite) (Fig. 12C). In the southern part of Grande Anse beach, veins and fractures that cut the debris flows are filled by calcite and heulandite (Fig. 12D).

Together with their geochemical evolution (see trace elements evolutions presented in previous paragraphs), the observed mineralogical evolution reveals that the Basal Complex offers a spectacular example of allochemical metamorphism in relation with hydrothermal fluid circulation during cooling of the magmatic arc, ending with supergene alterations.

\subsection{Metamorphic P-T conditions}

The mineral assemblages recognized within the metavolcanites from the Basal Complex are a diagnostic for subgreenschist facies conditions, close to the onset of the greenschist facies (Liou et al., 1985; Schiffman and Day, 1999; Robinson et al., 2005).

A first approach for a qualitative estimation of $\mathrm{P}-\mathrm{T}$ conditions is the use of available petrogenetic grids. Such grids have been determined for metabasites and can thus be used only for the studied andesitic meta-basalts (Liou et al., 1985; Frey and Robinson, 1999). At the transition between subgreenschist and greenschist facies, in the simplified basaltic system (i.e. $\mathrm{NCMASH}, \mathrm{Na}_{2} \mathrm{O}-\mathrm{CaO}-\mathrm{MgO}-\mathrm{Al}_{2} \mathrm{O}_{3}$ ) system, an invariant point (so-called CHEPPAQ) is identified, which separates a higher-pressure mineral association (actinolite + chlorite + epidote + pumpellyite + quartz) from a lower-pressure assemblage (prehnite + epidote + chlorite + quartz). Depending on the selected activity models for thermodynamic modeling, the $\mathrm{P}-\mathrm{T}$ position of the invariant point between prehnite bearing assemblages, pumpellyite bearing assemblages and greenschist facies assemblages varies between 3 and $4 \mathrm{kbar}$ and between 300 and $380^{\circ} \mathrm{C}$ (Liou et al., 1987; Frey et al., 1991; Powell et al., 1993; Beiersdorfer and Day, 1995; Day and Springer, 2005). Whatever the selected model, the metamorphic temperature for the mineralogical assemblages depicted in the studied samples is well constrained between 220 and $380^{\circ} \mathrm{C}$. For such a temperature range, the absence of clear pumpellyite + actinolite + chlorite + epidote assemblage suggests that metamorphic pressures did not exceed 2.5-3 kbar.

Thermobarometry is a second approach available and chlorite thermometry is particularly well adapted for lowgrade metamorphic rocks, particularly using recent thermodynamic calibrations (Lanari et al., 2014; Bourdelle and Cathelineau, 2015). The application of these geothermometer to all the analyzed chlorites in both andesitic meta-basalts and meta-rhyodacites, with the assumption that Total $\mathrm{Fe}=\mathrm{Fe}^{2+}$, indicates a temperature range of $230-320^{\circ} \mathrm{C}$, thus consistent with the previous temperature estimation. Pressure values can be roughly estimated by the application of the geobarometer of Brown (1977), to amphibole composition within andesitic meta-basalts, when this mineral is associated with albite, chlorite and iron oxide. With Na M4 values lower than 0.05 and $\mathrm{Al}^{\mathrm{iv}}$ below 0.5 the estimated pressure is less than 2 kbar. Furthermore, the values of the $\mathrm{K}_{\mathrm{D}} \mathrm{Mg}-\mathrm{Fe}$ for coexisting actinolite and chlorite range between 1.1 and 1.3, typical of metamorphic amphiboles under low-grade conditions (Robinson et al., 2004).

Furthermore, thermodynamic calculations were performed with the free energy minimization programs THERIAK and DOMINO (De Capitani and Petrakakis, 2010; updated software v. 4 February 2017) and the internally consistent thermodynamic "tcdb55c2d" database (Holland and Powell, 1998; updated Nov. 2003). However, thermodynamic modeling requires a strict definition of the chemical system to ensure 
it corresponds to the effective bulk chemistry equilibrated during the metamorphic peak event. The previously presented geochemical data demonstrate that a significant number of the studied samples were subject to severe chemical modifications during cooling and supergene alterations. REE patterns normalized to chondrite values (Fig. 5) allowed the identification of the samples that were not affected by late alterations and thus that best preserved the chemical system effective during metamorphic peak conditions.

Theses two samples (BT9_01-02) are meta-rhyodacites from Tillet creek (Fig. 5D). We calculated P-T pseudosections, at the whole rock scale with the metamorphic assemblage: albite + muscovite + chlorite + titanite + quartz + clinozoisite + ilmenite.

As a consequence of weathering under tropical conditions, the estimation of $\mathrm{Fe}^{3+}$ content in the studied samples is always questionable. We therefore used the values proposed for the Fe-oxidation state of sub-arc magmatism, proposed by Lee et al. (2010), and recently discussed and applied to metavolcanites by Verati et al. (2018). Following these previous studies, a maximum of $5 \%$ of $\mathrm{Fe}^{3+}$ for the composition of the metamorphic equilibrium has to be envisaged and thus two chemical systems, with 0 and $5 \%$ of $\mathrm{Fe}^{3+}$ were simulated.

The two pseudosections were calculated in the system $\mathrm{SiO}_{2}-\mathrm{Al}_{2} \mathrm{O}_{3}-\mathrm{TiO}_{2}-\mathrm{FeO}-\mathrm{MgO}-\mathrm{Na}_{2} \mathrm{O}-\mathrm{CaO}-\mathrm{K}_{2} \mathrm{O}-\mathrm{H}_{2} \mathrm{O}$, and assuming $\mathrm{H}_{2} \mathrm{O}$ in excess (Fig. 13). In the system calculated with $\mathrm{O}\left(\mathrm{Fe}_{2} \mathrm{O}_{3}\right)=0.29$ corresponding to a $5 \%$ conversion of all $\mathrm{Fe}$ as $\mathrm{FeO}$ to $\mathrm{Fe}_{2} \mathrm{O}_{3}$ (Fig. 13A), minerals accommodating $\mathrm{Fe}^{3+}$, like epidote or riebeckite are largely stabilized. Whatever the $\mathrm{Fe}^{3+}$ content, with $\mathrm{H}_{2} \mathrm{O}$ in excess in the system zeolites are particularly well developed, even under temperatures higher than $300^{\circ} \mathrm{C}$ and pressures higher than $1.5 \mathrm{kbar}$ (Figs. 13A and 13B). Moreover, there is no stability field that corresponds exactly to the observed mineralogical composition, as paragonite is systematically associated with muscovite. It is in the temperature range of $300-320^{\circ} \mathrm{C}$ for pressure higher than $1.4 \mathrm{kbar}$ for $5 \%$ of $\mathrm{Fe}_{2} \mathrm{O}_{3}$ and in the temperature range of 280 $320{ }^{\circ} \mathrm{C}$ for pressure higher than $1.7 \mathrm{kbar}$ for $0 \%$ of $\mathrm{Fe}_{2} \mathrm{O}_{3}$, that we can find the mineralogical association which is the closest to the one really observed, although two white micas are always present in the modeled pseudosections.

Therefore, it appears critical to test the $\mathrm{H}_{2} \mathrm{O}$ impact on the stability field of the mineral assemblages. Using the Theriakdomino program, it is possible to generate a $\mathrm{P}-\mathrm{X}\left(\mathrm{H}_{2} \mathrm{O}\right)$ equilibrium phase diagram at a fixed temperature. We choose a temperature of $280^{\circ} \mathrm{C}$ in agreement with chlorite thermometry results and two equilibrium diagrams were calculated respectively with 5 and $0 \% \mathrm{Fe}_{2} \mathrm{O}_{3}$ (Figs. $13 \mathrm{C}$ and $13 \mathrm{D}$ ). With $5 \%$ of $\mathrm{Fe}_{2} \mathrm{O}_{3}$ in the system, riebeckite is still well developed and two white micas are always stable together (Fig. 13A). It is only when we consider a phase diagram with all $\mathrm{Fe}$ as $\mathrm{FeO}(0 \%$ $\mathrm{Fe}_{2} \mathrm{O}_{3}$ ) (Fig. 13D), that we obtain the expected mineralogy. The association albite + ilmenite + chlorite + muscovite + clinozoisite + titanite + quartz is indeed for $0.60<\mathrm{X}\left(\mathrm{H}_{2} \mathrm{O}\right)$ $<0.75$ in the pressure range of $0.6-2.0 \mathrm{kbar}$. As demonstrated in Verati et al. (2018), in a totally different chemical system, the amount of $\mathrm{H}_{2} \mathrm{O}$ available within the metamorphic fluids appears to be a key parameter for the stability of the observed metamorphic assemblage of Basse-Terre.

All together, available petrogenetic grids, thermobarometry and pseudosection modeling provide coherent estimation of the metamorphic $\mathrm{P}-\mathrm{T}$ conditions suffered by the volcanic rocks of the Basal Complex in the range of $250-300^{\circ} \mathrm{C}$ and 0.6-2.0 kbar. This metamorphic evolution is the result of a high-temperature and low-pressure regime typically developed within magmatic arcs setting.

\section{Discussion}

\subsection{Finite strain pattern and deformation history}

Structural analysis allows the determination of the different directions of deformation through time during progressive cooling:

- N80-N100 for tectonic ductile structures;

- N110-N140 and N160-N10 for tectonic structures at the brittle-ductile transition;

- mainly N140-N150, and in a few cases N30-N50, N80-

N100 and N160-N10, for tectonic brittle structures.

Dissolution-schistosity planes highlight ductile deformation. Pressure solution is now widely regarded as a mechanism accomplishing fluid-assisted ductile deformation under lowtemperature conditions within the upper crust (Rutter, 1976; Gundersen et al., 2002; Gratier et al., 2013). However, strain is heterogeneous at all scales in the Basal Complex. Indeed, the regional finite strain pattern displays localized schistose domains surrounding lenses of undeformed country rocks, preserving primary magmatic structures. Structural mapping evidenced moderately dipping schistosity planes with a $\mathrm{N} 80^{\circ}-$ $100^{\circ}$ main and exclusive direction (Fig. 6A). This structural pattern with sub-horizontal undeformed lenses strongly suggests a regional flattening stress regime, characterized by a component of vertical shortening.

During progressive cooling of the Basal Complex formations, brittle-ductile (hydrothermal tectonic breccias) and brittle structures (fractures, faults) develop with several observable directions. The change in stress regime remains unknown.

We did not observe systematic relations between the orientation of the breccias and their colours. Furthermore, we did not decipher relative chronological criteria of crosscutting relationships between both directions of breccias, as the stepping criteria are repeatedly reversed at the outcrop scale. If we take into account these various observations, it seems preferable to interpret these two structural directions as being synchronous rather than the result of two superimposed extensive events in time.

It is also difficult to define a strict chronology between the different brittle structures. This is explained by the limited observation of outcrops displaying kinematics or intersections at the scale of the Basal Complex. For this reason, we propose two hypotheses. Although we cannot rule out that the activation of theses faults may be synchronous, similarly to what we observed along semi-brittle structures, scarce outcrop-scale evidences suggest that the N140-N150 trending faults are crosscutting the N30-N50 trending faults. At the regional scale this observation is corroborated by the $\mathrm{N} 50^{\circ}$ trending paleovalleys in which the St Rose Piton lavas have flowed and by the sharp N $150^{\circ}$ boundary west of La Perle lava flows that may result from faulting along the directions N140- 

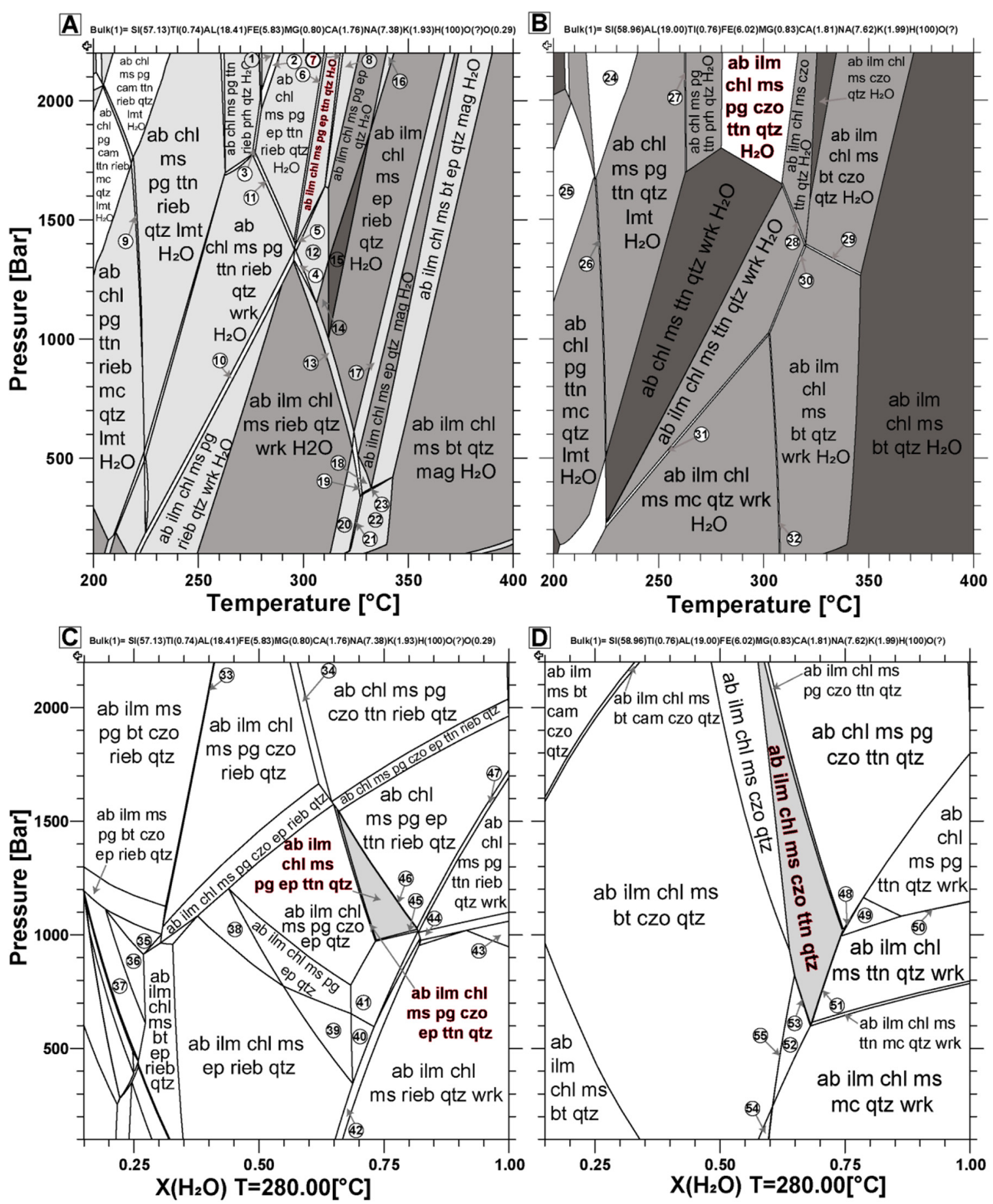

Fig. 13. Mineral abbreviations are from Kretz (1983). The main stable mineralogical assemblages are given, the others are listed in the Appendix Table A6. A: Calculated P-T pseudosection for a meta-rhyodacite sample (BT9-01) with $\mathrm{H}_{2} \mathrm{O}$ saturation and $5 \% \mathrm{Fe}^{3+}$ (of total iron). The rock composition, given as mol.\% oxide. Fields are colored with respect to their variances, darker colours indicate lower-variance assemblages. The stability fields written in red and bold correspond to the closest observed assemblage. $4=\mathrm{ab}$ ilm chl $\mathrm{ms} \mathrm{pg} \mathrm{ep} \mathrm{rieb} \mathrm{qtz} \mathrm{wrk} \mathrm{H}_{2} \mathrm{O}$; $5=\mathrm{ab}$ ilm chl ms pg ep ttn qtz wrk $\mathrm{H}_{2} \mathrm{O} ; 6=\mathrm{ab}$ ilm chl ms pg ep ttn rieb qtz $\mathrm{H}_{2} \mathrm{O} ; 7=\mathrm{ab}$ ilm chl ms pg czo ep ttn qtz $\mathrm{H}_{2} \mathrm{O} ; 8=\mathrm{ab}$ ilm chl ms pg czo ep qtz $\mathrm{H}_{2} \mathrm{O}$ and $12=\mathrm{ab}$ ilm chl ms pg ep qtz wrk $\mathrm{H}_{2} \mathrm{O}$; B: Calculated P-T pseudosection for a meta-rhyodacite sample (BT9-01) with $\mathrm{H}_{2} \mathrm{O}$ saturation and total iron as $\mathrm{Fe}^{2+}$. Rock composition is given as mol.\% oxide. Fields are colored with respect to their variances, darker colours indicate lower-variance assemblages. The stability field written in red and bold correspond to the closest observed assemblage. $28=\mathrm{ab}$ ilm chl ms czo tth qtz wrk $\mathrm{H}_{2} \mathrm{O} ; \mathrm{C}$ : P-X $\left(\mathrm{H}_{2} \mathrm{O}\right)$ equilibrium phase diagram calculated at $280^{\circ} \mathrm{C}$, using the same base composition of Figure $13 \mathrm{~A}$. The stability fields colored in grey correspond to the closest observed assemblage. $41=\mathrm{ab}$ ilm chl ms pg ep qtz wrk; $45=\mathrm{ab}$ ilm chl ms pg ep tth qtz wrk; $46=\mathrm{ab}$ ilm chl ms pg ep ttn rieb qtz; D: $\mathrm{P}-\mathrm{X}\left(\mathrm{H}_{2} \mathrm{O}\right)$ equilibrium phase diagram calculated at $280^{\circ} \mathrm{C}$, using the same base composition of Figure 13B. The stability field colored in grey corresponds to the observed assemblage. $51=\mathrm{ab}$ ilm chl $\mathrm{ms}$ czo ttn qtz wrk; $52=\mathrm{ab}$ ilm chl ms czo mc qtz; 53=ab ilm chl ms czo ttn mc qtz. 

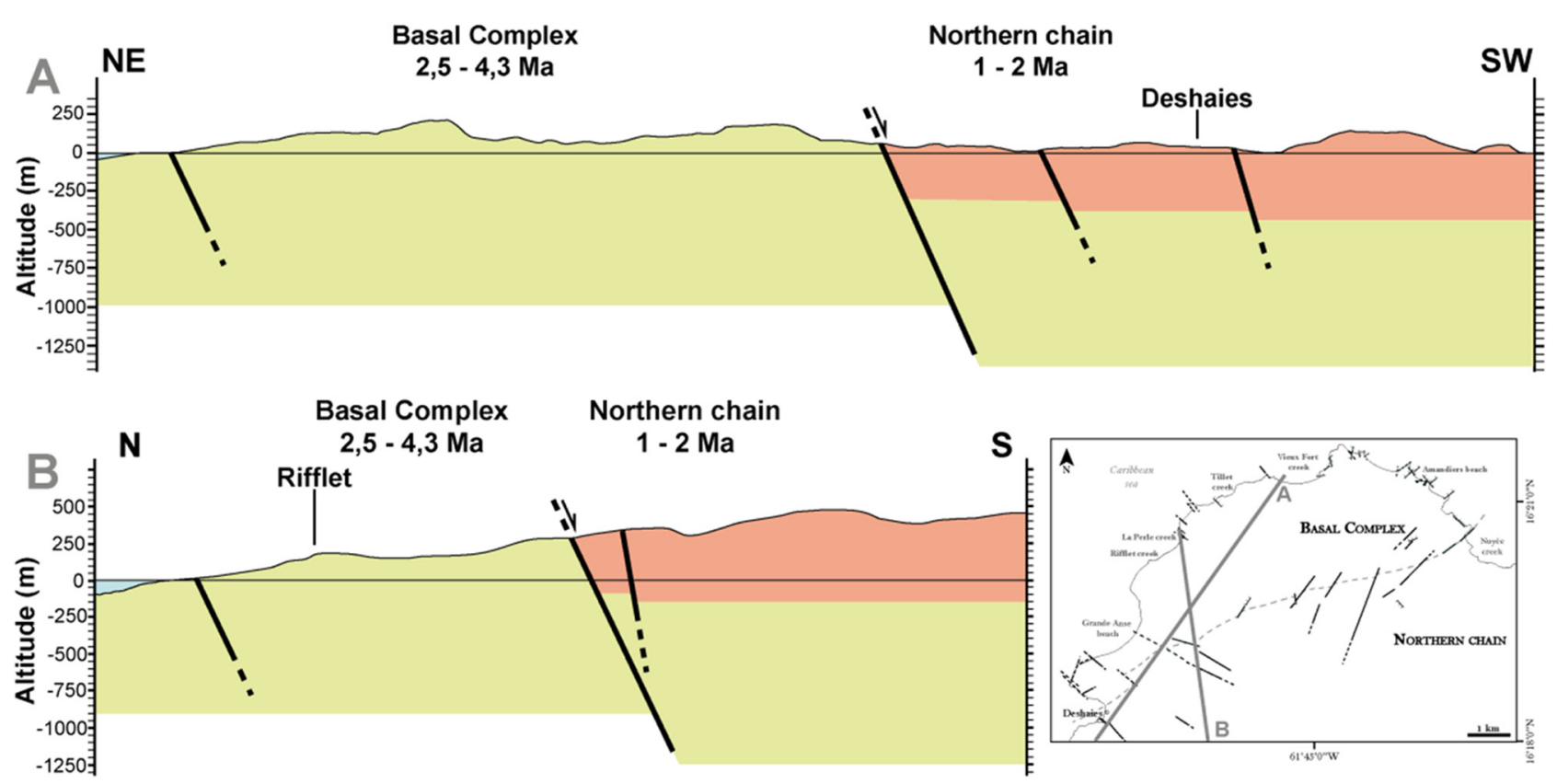

Fig. 14. Cross-sections showing the geometric relation between the two volcanic complexes (Basal Complex and Northern Chain).

N150 (see Fig. 6A). The N140-N150 faulting event seems to postdate the N30-N50 one. However, many studies (Bouysse, 1979; Bouysse and Westercamp, 1990; Feuillet et al., 2002, 2004; Corsini et al., 2011; Lardeaux et al., 2013; De Min, 2014; Legendre, 2018) have shown that the deformed areas of the Guadeloupe archipelago have a long history and that active deformation is largely conditioned by the reactivation of structures, emphasising structural heritage. Following this hypothesis, structures with different orientations can be reactivated at the same time. Moreover, our paleostress inversion of the whole dataset of kinematics measurements gives a pure-extensional stress regime $\sigma_{3}$ trending NE-SW (Fig. 6D).

On the scale of the Guadeloupe archipelago with onshore and offshore investigations (Feuillet et al., 2002, 2010, 2011; Thinon et al., 2010; Mathieu et al., 2011; Corsini et al., 2011; Laigle et al., 2013; Lardeaux et al., 2013; Münch et al., 2013; Leclerc et al., 2014), statistically, the N150-N10 structures are presented as the most recent ones, while the N40-N50 structures are the oldest in the proposed relative chronology. According to many authors, the N120N140 structures have been synchronously activated by transtension.

Finally, similar trends, observed in brittle, semi-brittle and ductile tectonic structures suggest strong inheritances within the crust of the volcanic arc of the Lesser Antilles and corroborates observations from previous workers along the Lesser Antilles volcanic arc (Corsini et al., 2011; Lardeaux et al., 2013; De Min et al., 2015; Legendre et al., 2018). In such a framework, the boundaries between volcanic complexes are possibly controlled by brittle normal faults, developed under recent to active extensional tectonic regimes, as it is the case for the geometric relation between the Basal Complex and the Northern Chain (Fig. 14).

\subsection{Petrological evolution of the Basal Complex}

The proposed new geological map shows a diversity of volcanic lithologies consistent with the magmatic differentiation of calc-alkaline series. Geochemical investigations allow the identification of a complete serie from basalticandesites to rhyodacites that has never been identified before. Even in the most altered parts of the Basal Complex, REE and multi-elements diagrams (Fig. 5) provide evidence of a triple geochemical signature: calc-alkaline magmatic differentiation, high-temperature transformation (metamorphism) and low-temperature sub-surface alteration.

These post-magmatic mineralogical transformations are the record of a progressive cooling of the Basal Complex through time and three main stages can be recognized:

- a high-temperature stage with albite, chlorite, white-micas, actinolite, biotite, prehnite, epidote, quartz, titanite, typical for sub-greenschist to greenschist facies conditions;

- a low-temperature re-equilibration stage under zeolite facies conditions with tridymite, chalcedony, calcite, quartz, chlorite, jarosite, heulandite and barite;

- and a sub-surface stage with development of clays minerals and gypsum typical for supergene alteration.

If we compare the calculated $\mathrm{P}-\mathrm{T}$ conditions with the values of 70.0 to $98.2 \pm 8.8^{\circ} \mathrm{C} / \mathrm{km}$ (conductive geotherm, Manga et al., 2012) measured for the present day geotherm near Basse-Terre, our data supports the idea that the development of this metamorphic pattern and the building of the active magmatic arc are synchronous. The temperatures reached during the Greenschist to sub-Greenschist facies metamorphic stage are high enough to lead significant chemical exchanges between contrasted rock types. In such a case potential $\mathrm{K}$ and Ar losses/enrichments, are still possible 


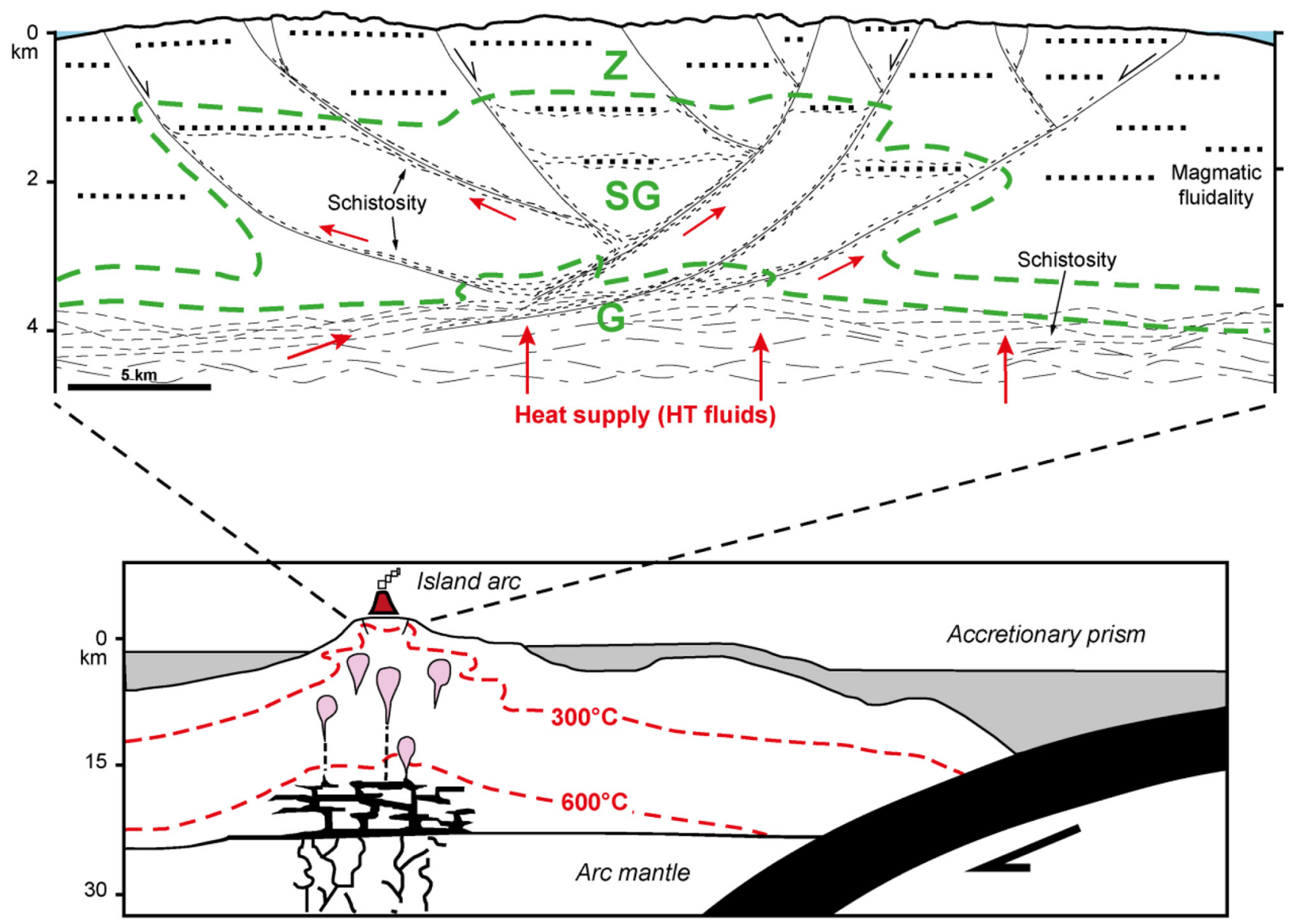

Fig. 15. Conceptual model for arc related metamorphism and deformation in the Lesser Antilles volcanic arc in Guadeloupe. The crustal thickness of the island arc is drawn after Kopp et al. (2011). The brittle/ductile transition is represented as a sub-horizontal horizon acting as a shear zone. The geometry of faults and the schistose zone pattern are purely indicative. $Z=$ Zeolite facies zone; $S G=S u b-G r e e n s c h i s t$ facies zone; $\mathrm{G}=$ Greenschist facies zone. Red arrows = Magmatic and hydrothermal fluid contribution.

in dacite lavas. Consequently, the new age of $4.3 \mathrm{Ma}$ obtained on the Deshaies eroded dome must be considered as a "maximal" age for the Basal Complex.

The mineralogical evolution, which reflects cooling (or exhumation), is consistent with the structural evolution, showing an evolution from ductile structures (controlled by dissolution-recrystallization process), to brittle-ductile (hydrothermal breccias) and brittle structures (fractures, faults). The Basal Complex is thus a key area to understand the thermomechanical evolution of the shallow crustal levels of active volcanic arcs. As a working hypothesis, we suggest that similar "arc-related metamorphism", although recognized on a small area of northern Basse-Terre of Guadeloupe, is a common feature at the scale of the whole Lesser Antilles arc, and could now be recognized in other eroded zones of the recent or ancient volcanic arcs as in St. Kitts or Martinique for example.

\subsection{Regional model for heat and fluid transfers within the upper crust of Lesser Antilles active arc}

Relationships between metamorphism and tectonics enable a conceptual model (Fig. 15) to be proposed including the depth of the brittle-ductile transition. If the conductive geothermal gradient is uniform (Manga et al., 2012; Verati et al., 2018), our observations can be extended to the whole island, and thus temperatures in the range of $250-300^{\circ} \mathrm{C}$ possibly occur at a depth of 3-4 km. Consequently, the faults observed at the surface, more often strongly dipping, must be rooted on the brittle-ductile transition, and potentially tend to be more horizontal at that transition depth. This rheological interface is then potentially a preferential pathway for regional heat and fluid transfers, and in connection to the already known fault network and/or to volcanic structures (interfaces between lava flows, volcanic fabrics,...), offering a system of connected physical vertical and more horizontal discontinuities able to drive the hydrothermal fluids circulation at the whole scale of Basse-Terre arc crust. This result opens new exciting perspectives first for the exploration of geothermal resources, only known and already exploited in the Bouillante bay (Bouchot et al., 2010; Calcagno et al., 2012; Verati et al., 2014), and second in a more general way for the understanding of genesis of metallic ore deposits in volcanic arcs, following the idea that epithermal systems are comparable to geothermal systems (White \& Hedenquist, 1995). 


\section{Conclusions}

In the northern part of the island of Basse-Terre of Guadeloupe, the Basal Complex, including the Deshaies eroded dome, is composed of a well-differentiated calcalkaline volcanic serie, with basaltic-andesites, andesites, dacites and rhyodacites. Its southern boundary corresponds to a series of faults of $\mathrm{N} 150^{\circ}$ and $\mathrm{N} 50^{\circ}$ main directions.

New ${ }^{40} \mathrm{Ar}-{ }^{39} \mathrm{Ar}$ dating on magmatic plagioclases demonstrates a magmatic activity with a significant time span, in the range of 4.3 to $2 \mathrm{Ma}$.

The Basal Complex offers a spectacular example of arc-related metamorphism in relation with a hydrothermal fluid circulation during the building and the cooling of the Lesser Antilles magmatic arc. Three main stages of postmagmatic mineralogical transformations record this evolution with: first a high-temperature stage under Greenschist to subGreenschist facies conditions $\left(0.6-2 \mathrm{kbar}\right.$ for $\left.250-300^{\circ} \mathrm{C}\right)$, a re-equilibration stage under Zeolite facies conditions and finally a sub-surface alteration stage. This metamorphism is consistent with the present day geothermal gradient measured near the northwestern coast of Basse-Terre Island (Manga et al., 2012).

In parallel with this metamorphic evolution, a significant deformation history has been characterized. The finite strain pattern consists in the development and superposition through time of N80-N100 oriented schistose domains, driven by pressure-solution processes, of hydrothermal breccias associated to N110-N140 and N160-N10 faults, and finally of brittle normal faults, with dominant trends N140-N150.

The Basal Complex is an exhumed and eroded piece of the shallow crustal levels of the Lesser Antilles volcanic arc and thus represents a key-target for understanding its whole thermo-mechanical evolution.

The depicted tectono-metamorphic evolution is compatible with brittle-ductile transition located at around $3-4 \mathrm{~km}$ deep at the scale of the Basse-Terre Island. In such a framework, steeply dipping normal faults are probably rooted on this rheological interface. The connection of brittle faults to schistose domains provides connected vertical and horizontal physical discontinuities allowing heat and hydrothermal fluid transfers at shallow depth within the Guadeloupe archipelago.

\section{Supplementary Material}

Appendix A: Raman spectrometry spectra used to complete mineral determination.

Table A1: Results of paleotensors obtained by field data inversion in the Basal Complex of the Basse-Terre de Guadeloupe.

Table A2: ${ }^{40} \mathrm{Ar} /{ }^{39} \mathrm{Ar}$ analyses results, ArArCalc files.

Table A3: New major element data set of whole-rock samples analysed for this study.

Table A4: New trace element data set of whole-rock samples analysed for this study.

Table A5: Microprobe analysis of metamorphic phases. $\mathrm{Ox}=$ oxygen number.

Table A6: All stable mineralogical assemblages listed in Figure 13. Mineral abbreviations are from Kretz (1983).
The Supplementary Material is available at http://www.bsgf.fr/ 10.1051/bsgf/2019011/olm.

Acknowledgment. This paper is a contribution to the GEOTREF program, funded by the French government with the program of "Investissements d'Avenir" and tutored by ADEME. We thank the researchers from the GEOTREF consortium for greatful discussions during the fieldwork campaigns in Guadeloupe and during scientific meetings. We sincerely would like to thank the reviews, the comments and the suggestions of Agnès Samper and Christoph von Hagke that significantly improved the manuscript. The authors thank Vivien Navelot for his donation of some samples and geochemical data, Matthieu Zanti for sampling preparation, Arthur Iemmolo for his technical support during ${ }^{40} \mathrm{Ar} /{ }^{39} \mathrm{Ar}$ analysis and Gabriel Monge for his welcome to CEMEF for the use of the X-ray Diffraction device.

\section{References}

Andreieff P, Bouysse P, Westercamp D. 1987. Géologie de l'arc insulaire des Petites Antilles, et évolution géodynamique de l'EstCaraïbes. Université de Bordeaux I, Bordeaux (France).

Angelier J. 1979. Determination of the mean principal directions of stresses for a given fault population. Tectonophysics 56: T17-T26. DOI: 10.1016/0040-1951(79)90081-7.

Angelier J, Mechler P. 1977. Sur une méthode graphique de recherche des contraintes principales également utilisables en tectonique et en séismologie : la méthode des dièdres droits. Bulletin de la Société géologique de France S7-XIX: 1309-1318. DOI: 10.2113/ gssgfbull.S7-XIX.6.1309.

Barnoud A, Bouligand C, Coutant O, Carlut J. 2017. Magnetic structure of Basse-Terre volcanic island (Guadeloupe, Lesser Antilles) inferred from 3D inversion of aeromagnetic data. Journal of Volcanology and Geothermal Research 348: 1-11. DOI: 10.1016/j.jvolgeores.2017.10.005.

Bas MJL, Maitre RWL, Streckeisen A, Zanettin B. 1986. A chemical classification of volcanic rocks based on the total alkali-silica diagram. Journal of Petrology 27: 745-750. DOI: 10.1093/ petrology/27.3.745.

Bau M. 1991. Rare-earth element mobility during hydrothermal and metamorphic fluid-rock interaction and significance of the oxidation state of europium. Chemical Geology 93: 219-230. DOI: 10.1016/0009-2541(91)90115-8.

Beach A. 1979. Pressure solution as a metamorphic process in deformed terrigenous sedimentary rocks. Lithos 12: 51-58. DOI: 10.1016/0024-4937(79)90062-8.

Beach A. 1982. Chemical processes in deformation at low metamorphic grades: Pressure solution and hydraulic fracturing. Episodes 4: 22-25.

Beiersdorfer RE, Day HW. 1995. Mineral paragenesis of pumpellyite in low-grade mafic rocks. In: Schiffman P, Day HW, eds. Lowgrade metamorphism of mafic rocks. Boulder, Colorado: Geological Society of America, Special Paper, pp. 5-28.

Blanc F. 1983. Corrélations chronologiques et géochimiques des formations volcaniques du Sud de La Basse-Terre de Guadeloupe (Petites Antilles) : début du cycle récent. Université Scientifique et Médicale de Grenoble, Grenoble (France).

Bouchot V, Traineau H, Guillou-Frottier L, Thinon I, Baltassat J-M, Fabriol H, et al. 2010. Assessment of the Bouillante Geothermal Field (Guadeloupe, French West Indies): Toward a conceptual model of the high temperature geothermal system. In : Proceedings 
of the World Geothermal Congress 2010, Bali, Indonesia, 25 29 April 2010, (International Geothermal Association).

Boudon G, Semet MP, Vincent PM. 1987. Magma and hydrothermally driven sector collapses: The 3100 and $11500 y$. B.P. eruptions of la Grande Découverte (la Soufrière) volcano, Guadeloupe, French West Indies. Journal of Volcanology and Geothermal Research 33: 317-323. DOI: 10.1016/0377-0273(87) 90021-7.

Boudon G, Semet MP, Vincent PM. 1989. The evolution of La Grande Découverte (La Soufrière) volcano, Guadeloupe (F.W.I.). In: Latter J, ed. Volcanic hazards: Assessment monitoring. IAVCEI Proceedings in Volcanology, Berlin, (Springer, Heidelberg, Berlin), pp. 86-109. DOI: 10.1007/978-3-642-73759-6_5.

Boudon G, Komorowski JC, Villemant B, Semet MP. 2008. A new scenario for the last magmatic eruption of La Soufrière of Guadeloupe (Lesser Antilles) in 1530 A.D. Evidence from stratigraphy radiocarbon dating and magmatic evolution of erupted products. Journal of Volcanology and Geothermal Research 178: 474-490. DOI: 10.1016/j.jvolgeores.2008.03.006.

Bourdelle F, Cathelineau M. 2015. Low-temperature chlorite geothermometry: A graphical representation based on a T-R2+-Si diagram. European Journal of Mineralogy 27: 617-626. DOI: 10.1127/ejm/2015/0027-2467.

Bouysse P. 1979. Caractères morphostructuraux et évolution géodynamique de l'arc insulaire des Petites Antilles (campagne ARCANTE 1). Bulletin du Bureau de Recherches géologiques et Minières 2: 185-210.

Bouysse P, Garrabé F. 1984. Évolution tectonique néogène des îles calcaires de l'archipel de Guadeloupe. Comptes Rendus de l'Académie des Sciences de Paris II: 763-766.

Bouysse P, Westercamp D. 1990. Subduction of Atlantic aseismic ridges and Late Cenozoic evolution of the Lesser Antilles island arc. Tectonophysics 175: 349-380. DOI: 10.1016/0040-1951(90) 90180-G.

Bouysse P, Westercamp D, Andreieff P. 1990. The Lesser Antilles island arc. In : Moore JC, Mascle A, eds. Proceedings of the Ocean Drilling Program Scientific Results, pp. 29-44.

Bouysse P, Garrabé F, Mauboussin T, Andreieff P, Battistini R, Carlier $\mathrm{P}$, et al. 1993. Carte géologique du département de La Guadeloupe, notice explicative: Marie-Galante et Îlets de La Petite-Terre, Scale 1:50.000. Orléans, France.

Braun J-J, Pagel M, Herbilln A, Rosin C. 1993. Mobilization and redistribution of REEs and thorium in a syenitic lateritic profile: A mass balance study. Geochimica et Cosmochimica Acta 57: 44194434. DOI: 10.1016/0016-7037(93)90492-F.

Braun J-J, Ngoupayou JRN, Viers J, Dupre B, Bedimo Bedimo J-P, Boeglin J-L, et al. 2005. Present weathering rates in a humid tropical watershed: Nsimi, South Cameroon. Geochimica et Cosmochimica Acta 69: 357-387. DOI: 10.1016/j. gca.2004.06.022.

Briden JC, Rex DC, Faller AM, Tomblin JF. 1979. K-Ar geochronology and palaeomagnetism of volcanic rocks in the Lesser Antilles island arc. Philosophical Transactions of the Royal Society A: Mathematical, Physical and Engineering Sciences 291: 485-528. DOI: 10.1098/rsta.1979.0040.

Brown EH. 1977. Phase equilibria among pumpellyite, lawsonite, epidote and associated minerals in low-grade metamorphic rocks. Contributions to Mineralogy and Petrology 64: 123-136. DOI: 10.1007/BF00371507.

Brown M. 2010. Paired metamorphic belts revisited. Gondwana Research 18: 46-59. DOI: 10.1016/j.gr.2009.11.004.

Brown GM, Holland JG, Sigurdsson H, Tomblin JF, Arculus RJ. 1977. Geochemistry of the Lesser Antilles volcanic island arc.
Geochimica et Cosmochimica Acta 41: 785-801. DOI: 10.1016/ 0016-7037(77)90049-7.

Calcagno P, Bouchot V, Thinon I, Bourgine B. 2012. A new 3D fault model of the Bouillante geothermal province combining onshore and offshore structural knowledge (French West Indies). Tectonophysics 526-529: 185-195. DOI: 10.1016/j. tecto.2011.08.012.

Carignan J, Hild P, Mevelle G, Morel J, Yeghicheyan D. 2001. Routine analyses of trace elements in geological samples using flow injection and low pressure on-line liquid chromatography coupled to ICP-MS: A study of geochemical reference materials BR, DR-N, UB-N, AN-G and GH. Geostandards and Geoanalytical Research 25: 187-198. DOI: 10.1111/ j.1751-908X.2001.tb00595.x.

Carlut J, Quidelleur X, Courtillot V, Boudon G. 2000. Paleomagnetic directions and $\mathrm{K} / \mathrm{Ar}$ dating of 0 to $1 \mathrm{Ma}$ lava flows from $\mathrm{La}$ Guadeloupe Island (French West Indies): Implications for timeaveraged field models. Journal of Geophysical Research: Solid Earth 105: 835-849. DOI: 10.1029/1999JB900238.

Chambefort I, Lewis B, Simpson MP, Bignall G, Rae AJ, Ganefianto N. 2017. Ngatamariki geothermal system: Magmatic to epithermal transition in the Taupo volcanic zone, New Zealand. Economic Geology 112: 319-346. DOI: 10.2113/econgeo.112.2.319.

Coombs DS. 1960. Lower-grade mineral facies in New Zealand. In : Proceedings of the 21st International Geological Congress, Copenhagen, pp. 339-351.

Cornée J-J, Léticée J-L, Münch P, Quillévéré F, Lebrun J-F, Moissette P, et al. 2012. Sedimentology, palaeoenvironments and biostratigraphy of the Pliocene-Pleistocene carbonate platform of Grande-Terre (Guadeloupe, Lesser Antilles forearc). Sedimentology 59: 1426-1451. DOI: 10.1111/j.1365-3091.2011.01311.x.

Cornu S, Lucas Y, Lebon E, Ambrosi J-P, Luizão F, Rouiller J, et al. 1999. Evidence of titanium mobility in soil profiles, Manaus, central Amazonia. Geoderma 91: 281-295. DOI: 10.1016/ S0016-7061(99)00007-5.

Corsini M, Lardeaux JM, Verati C, Voitus E, Balagne M. 2011. Discovery of lower cretaceous synmetamorphic thrust tectonics in French Lesser Antilles (La Désirade Island, Guadeloupe): Implications for Caribbean geodynamics. Tectonics 30: 1-15. DOI: $10.1029 / 2011$ TC002875.

Cotten J, Le Dez A, Bau M, Caroff M, Maury RC, Dulski P, et al. 1995. Origin of anomalous rare-earth element and yttrium enrichments in subaerially exposed basalts: Evidence from French Polynesia. Chemical Geology 119: 115-138. DOI: 10.1016/ 0009-2541(94)00102-E.

Dagain J. 1981. La mise en place du massif volcanique MadeleineSoufrière, Basse-Terre de Guadeloupe, Antilles. Université Paris Sud, Orsay.

Dagain J, Paterne M, Westercamp D. 1981. La mise en place du massif volcanique Madeleine-Soufrière, Basse-Terre de Guadeloupe, Antilles. Comptes Rendus de l'Académie des Sciences de Paris 292: 921-926.

Day HW, Springer RK. 2005. The first appearance of actinolite in the prehnite pumpellyite facies, Sierra Nevada, California. The Canadian Mineralogist 43: 89-104. DOI: 10.2113/gscan min.43.1.89.

De Capitani C, Petrakakis K. 2010. The computation of equilibrium assemblage diagrams with Theriak/Domino software. American Mineralogist 95: 1006-1016. DOI: 10.2138/am.2010.3354.

De Min L. 2014. Sismo-stratigraphie multi-échelles d'un Bassin d'avant-arc: le Bassin de Marie-Galante, Petites Antilles. Université des Antilles et de la Guyane, Pointe-à-Pitre (Guadeloupe). 
De Min L, Lebrun J-F, Cornee J-J, Münch P, Léticée J-L, Quillévéré F, et al. 2015. Tectonic and sedimentary architecture of the Karukéra spur: A record of the Lesser Antilles fore-arc deformations since the Neogene. Marine Geology 363: 15-37. DOI: 10.1016/j. margeo.2015.02.007.

De Reynal de Saint-Michel A. 1966. Carte géologique à l'échelle 1:50 000 du département de La Guadeloupe-Feuilles de Basse-Terre et des Saintes. Paris.

Delvaux D, Sperner B. 2003. New aspects of tectonic stress inversion with reference to the TENSOR program. Geological Society, London, Special Publications 212: 75-100. DOI: 10.1144/GSL. SP.2003.212.01.06.

Demets C, Jansma PE, Mattioli G, Dixon TH, Farina F, Bilham R, et al. 2000. GPS geodetic constraints on Carribbean-North America plate motion. Geophysical Research Letters 27: 437-440.

Dessert C, Lajeunesse E, Lloret E, Clergue C, Crispi O, Gorge C, et al. 2015. Controls on chemical weathering on a mountainous volcanic tropical island: Guadeloupe (French West Indies). Geochimica et Cosmochimica Acta 171: 216-237. DOI: 10.1016/j. gca.2015.09.009.

Dixon TH, Farina F, Demets C, Jansma P, Mann P, Calais E. 1998. Relative motion between the Caribbean and North American plates and related boundary zone deformation from a decade of GPS observations. Journal of Geophysical Research: Solid Earth 103: 15157-15182. DOI: 10.1029/97JB03575.

Ducea MN, Saleeby JB, Bergantz G. 2015. The architecture, chemistry, and evolution of continental magmatic arcs. Annual Review of Earth and Planetary Sciences 43: 299-331. DOI: 10.1146/annurev-earth-060614-105049.

Ernst WG. 1973. Blueschist metamorphism and $\mathrm{P}-\mathrm{T}$ regimes in active subduction zones. Tectonophysics 17: 255-272. DOI: 10.1016/ 0040-1951(73)90006-1.

Feuillet N, Manighetti I, Tapponnier P. 2001. Extension active perpendiculaire à la subduction dans l'arc des Petites Antilles (Guadeloupe, Antilles françaises). Comptes Rendus de l'Académie de Sciences-Série IIa: Sciences de la Terre et des Planètes 333: 583-590. DOI: 10.1016/S1251-8050(01)01543-9.

Feuillet N, Manighetti I, Tapponnier P, Jacques E. 2002. Arc parallel extension and localization of volcanic complexes in Guadeloupe, Lesser Antilles. Journal of Geophysical Research 107(B12): ETG 3 1-29. DOI: 10.1029/2001JB000308.

Feuillet N, Tapponnier P, Manighetti I, Villemant B, King GCP. 2004. Differential uplift and tilt of Pleistocene reef platforms and Quaternary slip rate on the Morne-Piton normal fault (Guadeloupe, French West Indies). Journal of Geophysical Research: Solid Earth 109: 1-18. DOI: 10.1029/2003JB002496.

Feuillet N, Leclerc F, Tapponnier P, Beauducel F, Boudon G, Le Friant A, et al. 2010. Active faulting induced by slip partitioning in Montserrat and link with volcanic activity: New insights from the 2009 GWADASEIS marine cruise data. Geophysical Research Letters 37: 1-6. DOI: 10.1029/2010GL042556.

Feuillet N, Beauducel F, Tapponnier P. 2011. Tectonic context of moderate to large historical earthquakes in the Lesser Antilles and mechanical coupling with volcanoes. Journal of Geophysical Research: Solid Earth 116: 1-26. DOI: 10.1029/2011JB008443.

Frey M, Robinson D. 1999. Low-grade metamorphism. Oxford: Blackwell, John Wiley \& Sons (Ed.).

Frey M, De Capitani C, Liou JG. 1991. A new petrogenetic grid for low-grade metabasites. Journal of Metamorphic Geology 9: 497509. DOI: 10.1111/j.1525-1314.1991.tb00542.x.

Gailler LS, Martelet G, Thinon I, Bouchot V, Lebrun JF, Münch P. 2013. Crustal structure of Guadeloupe Islands and the Lesser Antilles arc from a new gravity and magnetic synthesis. Bulletin de la Société géologique de France 184: 77-97. DOI: 10.2113/ gssgfbull.184.1-2.77.

Germa A, Quidelleur X, Labanieh S, Chauvel C, Lahitte P. 2011. The volcanic evolution of Martinique Island: Insights from $\mathrm{K}-\mathrm{Ar}$ dating into the Lesser Antilles arc migration since the Oligocene. Journal of Volcanology and Geothermal Research 208: 122-135. DOI: 10.1016/j.jvolgeores.2011.09.007.

Gratier J-P, Dysthe DK, Renard F. 2013. The role of pressure solution creep in the ductility of the Earth's upper crust, Ed. Advances in Geophysics. DOI: 10.1016/B978-0-12-380940-7.00002-0.

Gundersen E, Renard F, Dysthe DK, Bjørlykke K, Jamtveit B. 2002. Coupling between pressure solution creep and diffusive mass transport in porous rocks. Journal of Geophysical Research: Solid Earth 107: ECV 19-1-ECV 19-19. DOI: 10.1029/2001JB000287.

Hastie AR, Kerr AC, Pearce JA, Mitchell SF. 2007. Classification of altered volcanic island arc rocks using immobile trace elements: Development of the Th-Co discrimination diagram. Journal of Petrology 48: 2341-2357. DOI: 10.1093/petrology/egm062.

Hawkesworth CJ, Powell M. 1980. Magma genesis in the Lesser Antilles island arc. Earth and Planetary Science Letters 51: 297 308. DOI: 10.1016/0012-821X(80)90212-5.

Holland TJB, Powell R. 1998. An internally consistent thermodynamic data set for phases of petrological interest. Journal of Metamorphic Geology 16: 309-343.

Jébrak M. 1997. Hydrothermal breccias in vein-type ore deposits: A review of mechanisms, morphology and size distribution. Ore Geology Reviews 12: 111-134. DOI: 10.1016/S0169-1368(97) 00009-7.

Kettermann M, Von Hagke C, Van Gent HW, Grutzner C, Urai JL. 2016. Dilatant normal faulting in jointed cohesive rocks: A physical model study. Solid Earth 7: 843-856. DOI: 10.5194/se7-843-2016.

Kopp H, Weinzierl W, Becel A, Charvis P, Evain M, Flueh ER, et al. 2011. Deep structure of the central Lesser Antilles island arc: Relevance for the formation of continental crust. Earth and Planetary Science Letters 304: 121-134. DOI: 10.1016/j. eps1.2011.01.024.

Koppers AAP. 2002. ArArCALC-Software for 40Ar/39Ar age calculations. Computers \& Geosciences 28: 605-619. DOI: 10.1016/S0098-3004(01)00095-4.

Kretz R. 1983. Symbols for rock-forming minerals. American Mineralogist 68: 277-279.

Labanieh S. 2009. Géochimie de l'île de La Martinique aux Petites Antilles. Université Joseph-Fourier-Grenoble I, Grenoble (France).

Laigle M, Becel A, De Voogd B, Sachpazi M, Bayrakci G, Lebrun J-F, Evain M. 2013. Along-arc segmentation and interaction of subducting ridges with the Lesser Antilles Subduction forearc crust revealed by MCS imaging. Tectonophysics 603: 32-54. DOI: 10.1016/j.tecto.2013.05.028.

Lanari P, Wagner T, Vidal O. 2014. A thermodynamic model for ditrioctahedral chlorite from experimental and natural data in the system $\mathrm{MgO}-\mathrm{FeO}-\mathrm{Al}_{2} \mathrm{O}_{3}-\mathrm{SiO}_{2}-\mathrm{H}_{2} \mathrm{O}$ : Applications to $\mathrm{P}-\mathrm{T}$ sections and geothermometry. Contributions to Mineralogy and Petrology 167: 1-19. DOI: 10.1007/s00410-014-0968-8.

Lardeaux JM, Münch P, Corsini M, Cornée J-J, Verati C, Lebrun J-F, et al. 2013. La Désirade Island (Guadeloupe, French West Indies): A key target for deciphering the role of reactivated tectonic structures in Lesser Antilles arc building. Bulletin de la Société géologique de France 184: 21-34. DOI: 10.2113/ gssgfbull.184.1-2.21.

Leclerc F, Feuillet N, Cabioch G, Deplus C, Lebrun J-F, Bazin S, et al. 2014. The Holocene drowned reef of Les Saintes plateau as witness 
of a long-term tectonic subsidence along the Lesser Antilles volcanic arc in Guadeloupe. Marine Geology 355: 115-135. DOI: 10.1016/j.margeo.2014.05.017.

Lee J-Y, Marti K, Severinghaus JP, Kawamura K, Yoo H-S, Lee JB, et al. 2006. A redetermination of the isotopic abundances of atmospheric Ar. Geochimica et Cosmochimica Acta, 4507-4512.

Lee C-TA, Luffi P, Le Roux V, Dasgupta R, Albaréde F, Leeman WP. 2010. The redox state of arc mantle using $\mathrm{Zn} / \mathrm{Fe}$ systematics. Nature 468: 681-685. DOI: 10.1038/nature09617.

Legendre L. 2018. Évolution tectonique du Nord de l'arc des Petites Antilles. Université des Antilles, Pointe-à-Pitre (Guadeloupe).

Legendre L, Philippon M, Münch P, Leticée J-L, Noury M, Maincent G, et al. 2018. Trench bending initiation: Upper plate strain pattern and volcanism. Insights from the Lesser Antilles arc, St. Barthelemy Island, French West Indies. Tectonics 37: 27772797. DOI: $10.1029 / 2017$ TC004921.

Liou JG, Maruyama S, Cho M. 1985. Phase equilibria and mixed parageneses of metabasites in low-grade metamorphism. Mineralogical Magazine 49: 321-333. DOI: 10.1180/min mag.1985.049.352.03.

Liou JG, Mauyama S, Cho M. 1987. Very low-grade metamorphism of volcanic and volcaniclastic rocks-mineral assemblages and mineral facies. In : Frey M, ed. Low temperature metamorphism. Blackie, Glasgow, pp. 59-113.

Lloret E, Dessert C, Gaillardet J, Albéric P, Crispi O, Chaduteau C, et al. 2011. Comparison of dissolved inorganic and organic carbon yields and fluxes in the watersheds of tropical volcanic islands, examples from Guadeloupe (French West Indies). Chemical Geology 280: 65-78. DOI: 10.1016/j.chemgeo.2010.10.016.

Ma J-L, Wei G-J, Xu Y-G, Long W-G, Sun W-D. 2007. Mobilization and re-distribution of major and trace elements during extreme weathering of basalt in Hainan Island, South China. Geochimica et Cosmochimica Acta 71: 3223-3237. DOI: 10.1016/j. gca.2007.03.035.

Manga M, Hornbach MJ, Le Friant A, Ishizuka O, Stroncik N, Adachi T, et al. 2012. Heat flow in the Lesser Antilles island arc and adjacent back arc Grenada basin. Geochemistry, Geophysics, Geosystems 13: 1-19. DOI: 10.1029/2012GC004260.

Mathieu L. 2010. The structure of Guadeloupe, Maderas and Mt Cameroon volcanoes and the impact of strike-slip movements. Université Blaise Pascal-Clermont-Ferrand II, Trinity College Dublin, Clermont-Ferrand (France) and Dublin (Ireland).

Mathieu L, Van Wyk de Vries B, Pilato M, Troll VR. 2011. The interaction between volcanoes and strike-slip, transtensional and transpressional fault zones: Analogue models and natural examples. Journal of Structural Geology 33: 898-906. DOI: 10.1016/j.jsg.2011.03.003.

Mathieu L, Van Wyk de Vries B, Mannessiez C, Mazzoni N, Savry C, Troll VR. 2013. The structure and morphology of the Basse-Terre Island, Lesser Antilles volcanic arc. Bulletin of Volcanology 75: 115. DOI: 10.1007/s00445-013-0700-y.

Maury RC, Westbrook GK, Baker PE, Bouysse P, Westercamp D. 1990. Chapter 5: Geology of the Lesser Antilles. In: Dengo G, Case JE, eds. The geology of North America, Vol. H. Boulder, Colorado, pp. 141-166.

Melfi AJ, Subies F, Nahon D, Formoso MLL. 1996. Zirconium mobility in bauxites of Southern Brazil. Journal of South American Earth Sciences 9: 161-170. DOI: 10.1016/0895-9811(96)00003-X.

Michard A. 1989. Rare earth element systematics in hydrothermal fluids. Geochimica et Cosmochimica Acta 53: 745-750. DOI: 10.1016/0016-7037(89)90017-3.

Michard A, Albarède F, Michard G, Minster JF, Charlou JL. 1983. Rare-earth elements and uranium in high-temperature solutions from East Pacific Rise hydrothermal vent field $\left(\mathrm{N}^{\mathrm{o}} 13\right)$. Nature 303: 795-797. DOI: 10.1038/303795a0.

Miyashiro A. 1967. Orogeny regional metamorphism and magmatism in the Japanese Islands. Geological Society of Denmark 17: 390 446.

Münch P, Lebrun JF, Cornee JJ, Thinon I, Guennoc P, Marcaillou BJ, et al. 2013. Pliocene to Pleistocene carbonate systems of the Guadeloupe archipelago, French Lesser Antilles: A land and sea study (the KaShallow project). Bulletin de la Société géologique de France 184: 99-110. DOI: 10.2113/gssgfbull.184.1-2.99.

Münch P, Cornee J-J, Lebrun JF, Quillevere F, Verati C, MelinteDobrinescu M, et al. 2014. Pliocene to Pleistocene vertical movements in the forearc of the Lesser Antilles subduction: Insights from chronostratigraphy of shallow-water carbonate platforms (Guadeloupe archipelago). Journal of the Geological Society 171: 329-341. DOI: 10.1144/jgs2013-005.

Nahon D, Merino E. 1996. Pseudomorphic replacement versus dilation in laterites: Petrographic evidence, mechanisms, and consequences for modelling. Journal of Geochemical Exploration 57: 217-225. DOI: 10.1016/S0375-6742(96)00038-6.

Navelot V, Géraud Y, Favier A, Diraison M, Corsini M, Lardeaux J$\mathrm{M}$, et al. 2018. Petrophysical properties of volcanic rocks and impacts of hydrothermal alteration in the Guadeloupe Archipelago (West Indies). Journal of Volcanology and Geothermal Research 360: 1-21. DOI: 10.1016/j.jvolgeores.2018.07.004.

Oxburgh ER, Turcotte DL. 1970. Thermal structure of island arcs. GSA bulletin 81: 1665-1688. DOI: 10.1130/0016-7606(1970)81 [1665:TSOIA]2.0.CO;2.

Passchier CW, Trouw RAJ. 2005. Microtectonics, 2nd ed. Berlin, Heidelberg: Springer.

Patino LC, Velbel MA, Price JR, Wade JA. 2003. Trace element mobility during spheroidal weathering of basalts and andesites in Hawaii and Guatemala. Chemical Geology 202: 343-364. DOI: 10.1016/j.chemgeo.2003.01.002.

Patrier P, Bruzac S, Pays R, Beaufort D, Bouchot V, Verati C, Gadalia A. 2013. Occurrence of K-feldspar-bearing hydrothermal breccias in the Bouillante geothermal field (Basse-Terre-Guadeloupe). Bulletin de la Société géologique de France 184: 119-128. DOI: 10.2113/gssgfbull.184.1-2.119.

Pearce JA. 1996. A user's guide to basalt discrimination diagrams. In : Wyman DA, ed. Trace element geochemistry of volcanic rocks: Application to massive sulphide exploration. Geological Association of Canada, Short Course Notes, pp. 79-113.

Peccerillo A, Taylor SR. 1976. Geochemistry of Eocene calc-alkaline volcanic rocks from the Kastamonu area, Northern Turkey. Contributions to Mineralogy and Petrology 58: 63-81. DOI: 10.1007/BF00384745.

Powell CM. 1979. A morphological classification of rock cleavage. Tectonophysics 58: 21-34. DOI: 10.1016/0040-1951(79)90320-2.

Powell WG, Carmichael DM, Hodgson CJ. 1993. Thermobarometry in a subgreenschist to greenschist transition in metabasites of the Abitibi greenstone belt, Superior Province, Canada. Journal of Metamorphic Geology 11: 165-178. DOI: 10.1111/ j.1525-1314.1993.tb00138.x.

Rad S, Rivé K, Vittecoq B, Cerdan O, Allègre CJ. 2013. Chemical weathering and erosion rates in the Lesser Antilles: An overview in Guadeloupe, Martinique and Dominica. Journal of South American Earth Sciences 45: 331-344. DOI: 10.1016/j.jsames.2013.03.004.

Renne PR, Mundil R, Balco G, Min K, Ludwig KR. 2010. Joint determination of $40 \mathrm{~K}$ decay constants and $40 \mathrm{Ar}^{*} / 40 \mathrm{~K}$ for the Fish Canyon sanidine standard, and improved accuracy for $40 \mathrm{Ar} / 39 \mathrm{Ar}$ geochronology. Geochimica et Cosmochimica Acta 74: 53495367. DOI: 10.1016/j.gca.2010.06.017. 
Ricci J, Lahitte P, Quidelleur X. 2015a. Construction and destruction rates of volcanoes within tropical environment: Examples from the Basse-Terre Island (Guadeloupe, Lesser Antilles). Geomorphology 228: 597-607. DOI: 10.1016/j.geomorph.2014.10.002.

Ricci J, Quidelleur X, Lahitte P. 2015b. Volcanic evolution of central Basse-Terre Island revisited on the basis of new geochronology and geomorphology data. Bulletin of Volcanology 77: 84. DOI: 10.1007/s00445-015-0970-7.

Ricci J, Quidelleur X, Pallares C, Lahitte P. 2017. High-resolution KAr dating of a complex magmatic system: The example of BasseTerre Island (French West Indies). Journal of Volcanology and Geothermal Research 345: 142-160. DOI: 10.1016/j.jvol geores.2017.07.013.

Robinson D, Bevins RE, Aguirre L, Vergara M. 2004. A reappraisal of episodic burial metamorphism in the Andes of central Chile. Contributions to Mineralogy and Petrology 146: 513-528. DOI: 10.1007/s00410-003-0516-4.

Robinson D, Bevins RE, Rubinstein N. 2005. Subgreenschist facies metamorphism of metabasites from the Precordillera terrane of western Argentina; constraints on the later stages of accretion onto Gondwana. European Journal of Mineralogy 17: 441-452. DOI: 10.1127/0935-1221/2005/0017-0441.

Rowland JV, Simmons SF. 2012. Hydrologic, magmatic, and tectonic controls on hydrothermal flow, Taupo volcanic zone, New Zealand: Implications for the formation of epithermal vein deposits. Economic Geology 107: 427-457. DOI: 10.2113/econ geo.107.3.427.

Rutter EH. 1976. The kinetics of rock deformation by pressure solution. Philosophical Transactions of the Royal Society London 283: 203-219. DOI: 10.1098/rsta.1976.0079.

Sak PB, Navarre-Sitchler AK, Miller C, Daniel CC, Gaillardet J, Buss HL, et al. 2010. Controls on rind thickness on basaltic andesite clasts weathering in Guadeloupe. Chemical Geology 276: 129-143. DOI: $10.1016 /$ j.chemgeo.2010.05.002.

Samper A, Quidelleur X, Lahitte P, Mollex D. 2007. Timing of effusive volcanism and collapse events within an oceanic arc island: Basse-Terre, Guadeloupe archipelago (Lesser Antilles Arc). Earth and Planetary Science Letters 258: 175-191. DOI: 10.1016/ j.eps1.2007.03.030.

Samper A, Quidelleur X, Komorowski J-C, Lahitte P, Boudon G. 2009. Effusive history of the Grande Découverte Volcanic Complex, southern Basse-Terre (Guadeloupe, French West Indies) from new K-Ar Cassignol-Gillot ages. Journal of Volcanology and Geothermal Research 187: 117-130. DOI: 10.1016/j.jvol geores.2009.08.016.

Schiffman P, Day HW. 1999. Petrological methods for the study of very low-grade metabasites. In: Frey M, Robinson D, eds. Very low-grade metamorphism. Oxford, UK: Blackwell Publishing Ltd., pp. 108-142. DOI: 10.1002/9781444313345.ch4.

Schumacher JC. 1997. The estimation of ferric iron in electron microprobe analysis of amphiboles. Mineralogical Magazine 61: 312-321. DOI: 10.1017/S0026461X00011397.

Sibson RH. 1977. Fault rocks and fault mechanisms. Journal of the Geological Society 133: 191-213. DOI: 10.1144/gsigs.133.3.0191.
Sillitoe RH, Perelló J. 2005. Andean copper province-Tectonomagmatic settings, deposit types, metallogeny, exploration, and discovery. Society of Economic Geologists, Economic Geology 100th Anniversary Volume, 845-890.

Sun S-S, McDonough WF. 1989. Chemical and isotopic systematics of oceanic basalts: Implications for mantle composition and processes. Geological Society, London, Special Publications 42: 313-345. DOI: 10.1144/GSL.SP.1989.042.01.19.

Taylor SR, McLennan SM. 1995. The geochemical evolution of the continental crust. Reviews of Geophysics 33: 241. DOI: 10.1029/ 95RG00262.

Thinon I, Guennoc P, Bitri A, Truffert C. 2010. Study of the Bouillante Bay (West Basse-Terre Island shelf): Contribution of geophysical surveys to the understanding of the structural context of Guadeloupe (French West Indies-Lesser Antilles). Bulletin de la Société géologique de France 181: 51-65. DOI: 10.2113/ gssgfbull.181.1.51.

Verati C, Patrier-Mas P, Lardeaux J-M, Bouchot V. 2014. Timing of geothermal activity in an active island-arc volcanic setting: First 40Ar/39Ar dating from Bouillante geothermal field (Guadeloupe, French West Indies). Geological Society, London, Special Publications 378: 285-295. DOI: 10.1144/SP378.19.

Verati C, Mazabraud Y, Lardeaux J-M, Corsini M, Schneider D, Voitus E, et al. 2016. Tectonic evolution of Les Saintes archipelago (Guadeloupe, French West Indies): Relation with the Lesser Antilles arc system. Bulletin de la Société géologique de France 187: 3-10. DOI: 10.2113/gssgfbull.187.1.3.

Verati C, Lardeaux J-M, Favier A, Corsini M, Philippon M, Legendre L. 2018. Arc-related metamorphism in the Guadeloupe archipelago (Lesser Antilles active island arc): First report and consequences. Lithos 320-321: 592-598. DOI: 10.1016/j.lithos.2018.08.005.

Westercamp D. 1979. Diversity, structural control and origin of recent volcanism in the Lesser Antilles island arc. Bulletin du Bureau de Recherches géologiques et Minières Section IV: 211-226.

Westercamp D. 1988. Magma generation in the Lesser Antilles: Geological constraints. Tectonophysics 149: 145-163. DOI: 10.1016/0040-1951(88)90123-0.

Westercamp D, Tazieff H. 1980. Guide géologiques régionaux, Martinique, Guadeloupe, Saint-Martin, La Désirade. Paris : Elsevier M.

White NC, Hedenquist JW. 1995. Epithermal gold deposits: Styles, characteristics and exploration. SEG Newsl 23: 1-9.

Winchester JA, Floyd PA. 1977. Geochemical discrimination of different magma series and their differentiation products using immobile elements. Chemical Geology 20: 325-343. DOI: 10.1016/0009-2541(77)90057-2.

Woodcock NH, Mort K. 2008. Classification of fault breccias and related fault rocks. Geological Magazine 145: 435-440. DOI: 10.1017/S0016756808004883.

Zami F, Quidelleur X, Ricci J, Lebrun J-F, Samper A. 2014. Initial sub-aerial volcanic activity along the central Lesser Antilles inner arc: New $\mathrm{K}-\mathrm{Ar}$ ages from Les Saintes volcanoes. Journal of Volcanology and Geothermal Research 287: 12-21. DOI: 10.1016/ j.jvolgeores.2014.09.011.

Cite this article as: Favier A, Lardeaux J-M, Legendre L, Verati C, Philippon M, Corsini M, Münch P, Ventalon S. 2019. Tectonometamorphic evolution of shallow crustal levels within active volcanic arcs. Insights from the exhumed Basal Complex of Basse-Terre (Guadeloupe, French West Indies), BSGF - Earth Sciences Bulletin 190: 10. 